\title{
Muhasebe Meslek Mensuplarının Etik Yaklaşımları ile Hileye Yönelme Eğilimleri Arasındaki İlişkiye Yönelik Bir Araştırma: Ankara Örneği*
}

\section{A Research on the Relationship Between Ethical Approaches of Professional Accountants and Fraud Tendencies: The Case of Ankara}

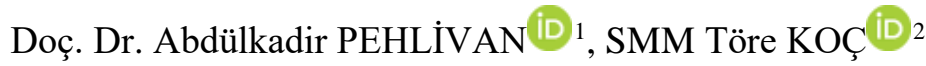

\begin{abstract}
$\ddot{O} z$
Günümüzde hile kavramı, birçok anlamda işletmeleri ve çalışanları ciddi oranda etkileyen, yadsınamaz boyutlarda dünya ekonomisine ve sektörlere zarar veren bir unsur olarak karşımıza çıkmaktadır. Hileli işlemlerin araştırılmasının yanında kanunlarda yapılan revizyonlar ve mesleki kuruluşlara yüklenen sorumluluklar artmış olsa da hile eylemleri çok fazla engellenememiştir. Hile ile mücadelede karşımıza çıan önemli mesleki unsurlardan birisi etiktir ve her meslekteki gibi muhasebe sürecinde meslek elemanlarının etik konusunda öncelikleri vardır. Çalışmada muhasebe meslek mensuplarının etik değerlere ve hileye bakış açılarının tespit edilmesi amacıyla nicel bir uygulamaya yer verilmiştir. Bu kapsamda, muhasebe mesleğinde aktif olarak çalışan 393 kişiye mesleki etik değer ve hile konularına bakışlarını ve etik ile hile arasındaki ilişkiyi araştıran bir anket formu gönderilmiş ve ulaştırılmıştır. Bu formlardan 360' 1 eksiksiz ve sağlıklı olarak analiz kapsamında değerlendirmeye alınmıştır. Anket uygulanan kişilerin yaşı, cinsiyeti, meslekteki tecrübesi ve bağımlı veya bağımsız çalıştığına ilişkin demografik bilgileri araştırma kapsamına alınmış, meslek mensuplarını hileye yönelten iç ve dış unsurların belirlenmesi amaçlanmıştır. Araştırma kapsamında oluş̧urulan model ve hipotezler çerçevesinde demografik faktörlerin fark testlerinde t-testi ve Anova analizleri, değişsenler arasındaki ilişkilerin tespitinde ise korelasyon ve regresyon analizine başvurulmuştur. Araştırma sonucunda elde edilen bulgular, etik değer algılarının hileye yönelme eğilimini etkilediğini istatistiksel anlamda ortaya koymuştur. Bu sonuçlara göre etik değerler ile hile arasında negatif bir ilişki söz konusudur.
\end{abstract}

Anahtar Kelimeler: Hile, meslek etiği, muhasebe mesleği, ekonomi

Makale Türü: Araştırma

\begin{abstract}
Today, the concept of fraud, undeniably has significant effects on businesses, employees and harms the world economy and sectors in many ways. In addition to investigating fraudulent transactions, the revisions made to the law and the responsibilities imposed on professional organizations have increased, fraudulent acts could not be prevented too much. One of the important professional elements in combating frauds is ethics. As in every profession, individuals who are members of accounting profession have priorities and responsibilities about ethics in the processes related to accounting profession. In the study, a quantitative application has been made in order to determine the ethical values and fraud aspects of professional accountants. In this context, a questionnaire form which investigates the professional ethics values and fraud issues as well as the relationship between ethics and fraud has been sent and delivered to 393 people who are working actively in the accounting profession. 360 respondents who responded correctly to these questionnaires were evaluated and included in the statistical analyses. The age, gender and demographic

\footnotetext{
* Bu makale "Muhasebe Meslek Mensuplarının Etik Yaklaşımları ile Hileye Yönelme Eğilimleri Arasındaki İlişkiye Yönelik Bir Araştırma: Ankara Örneği” isimli yüksek lisans tezinden türetilmiştir.

${ }^{1}$ Karadeniz Teknik Üniversitesi, İktisadi ve İdari Bilimler Fakültesi, apehlivan@ktu.edu.tr.

${ }^{2}$ Karadeniz Teknik Üniversitesi, Sosyal Bilimler Enstitüsü, tore406@gmail.com.
}

Atıf için (to cite): Pehlivan, A. ve Koç, T. (2020). Muhasebe meslek mensuplarının etik yaklaşımları ile hileye yönelme eğilimleri arasındaki ilişkiye yönelik bir araştırma: Ankara örneği. Afyon Kocatepe Üniversitesi Sosyal Bilimler Dergisi, 22(4), $1067-1088$. 
characteristics of the surveyed individuals were examined within the scope of the study. It is aimed to determine the internal and external elements that direct professional members to fraud. In the framework of the models and hypotheses created within the scope of the study, $t$-test and Anova analyses were used for the difference tests of the demographic factors and the correlation and regression analysis were used to determine the relationships between the variables. The findings obtained from the study showed that the perception of ethical values affect the tendency towards fraud. According to these results, there is a negative relationship between ethical values and cheating.

Keywords: Fraud, professional ethics, accounting profession, economics

Paper Type: Research

\section{Giriş}

Tarafsızlık, gizlilik, dürüstlük, güvenilirlik ve sorumluluk gibi meslek etiği kuralları muhasebe meslek mensuplarının sunduğu bilgilerin doğru ve güvenilir olmasına önemli katkılar sağlamaktadır. Sunulan finansal bilgilerin güvenilir olması büyük ölçüde meslek mensuplarının hileli davranışlardan uzak durmaları ile mümkündür.

Hileli finansal bilgiler yatırımcıların zarar görmesi, piyasalarda etkinliğin azalması, işletmelerin iflas etmesi veya büyük kayıplar yaşaması, finansal bilgilere, sisteme ve muhasebecilere olan güvenin sarsılması gibi birtakım sorunlara neden olabileceği için genel ekonomik sistem üzerinde olumsuz etki yapacaktır. Söz konusu etkinin nedenlerinin ortadan kaldırılmasına yönelik çözüm önerilerinin geliştirilmesi, genelde ekonomiye; özelde ise devlete, işletmelere, topluma ve bireylere fayda sağlayacaktır.

Özetle, yaptıkları işlemlerle devleti, işletmeleri, bireyleri, ekonomiyi etkileyen muhasebe meslek mensuplarının, işlerini yasalara ve meslek etik kurallarına uygun olarak yapmamalarının, başka bir ifadeyle hileli işlemlere başvurmalarının nedenleri, araştırılmaya değer önemli bir problem kaynağıdır. Bu noktada meslek mensuplarının hileye yönelme eğilimlerinin önüne geçilmesinde etik değerlerin büyük bir payı olduğu düşünülmektedir.

Araştırma, muhasebe meslek mensuplarının mesleki etik değerlere yaklaşımları ile hileye yönelme eğilimleri arasındaki ilişkiyi incelemeyi amaçlamaktadır. Bu bağlamda muhasebe meslek mensuplarını hileye yönlendiren içsel ve dişsal unsurların belirlenmesine yönelik oluşturulan model doğrultusunda ele alınan değişkenler arasındaki ilişkilerin ve bu ilişkilerin yönünün ve demografik faktörlerin etkisinin ortaya konulması amaçlanmaktadır. Nihayetinde, araştırmanın sonuçları itibariyle muhasebe meslek mensuplarının hile karşısındaki durumuna ilişsin profilinin ortaya konulması ile literatüre bu yönde katkı sağlanması düşünülmektedir.

\section{Muhasebe Meslek Mensuplarını Hileye Yönelten Sebepler}

Muhasebe meslek mensuplarının mesleklerini icra ederken hileli işlemler yapmaları önemli bir problem alanıdır. Bu problemin nedenlerinin tespiti ve bu nedenlerin ortadan kaldırılmasına yönelik çözüm önerilerinin geliştirilmesi, genel olarak ekonomiye ve özelde de devlete, işletmelere, topluma ve bireylere fayda sağlayacaktır. Zira muhasebe hilesi yapılması durumunda bundan başta devlet olmak üzere, işletmeler, toplum, bireyler ve ekonomi bir bütün olarak zarar görmektedir.

Devlet zarar görmektedir; zira, devletin en önemli gelir kaynağı olan verginin sağlıklı tahakkuku ve tahsili için muhasebe meslek mensuplarının işlerini yasalara ve meslek etik kurallarına uygun olarak yapmaları gerekmektedir. Yapmazlarsa devlet harcamalarının temel kaynağı olan vergiler yeterli miktarda tahsil edilemeyecektir. Bu da devletin fonksiyonlarını iyi bir şekilde yerine getirmesini engelleyecektir. 
Yatırımcılar zarar görmektedir; zira muhasebeciler tarafindan gerçeği yansıtmayan finansal tablolar hazırlanması durumunda, bu finansal tablolara bakarak karar alan yatırımcılar doğru kararlar alamayacaklardır.

İşletmeler zarar görmektedir; zira finansal tabloları gerçeği yansıtmayan bu işletmeler, zamanla faaliyetlerini sürdürmekte zorlanacaklar ve bir süre sonra faaliyetlerini sonlandırma riskiyle karşı karşıya geleceklerdir. $\mathrm{Bu}$ durumda bu firmalarda çalışan kişiler işlerini kaybedecekler, bahse konu olan firmalara mal tedarik eden diğer firmalar, dolayısıyla ekonomi olumsuz etkilenmiş olacaktır.

Ekonomide birçok soruna yol açan muhasebe hileleri (etik dışı davranışlar) uluslararası muhasebe literatüründe geniş araştırmaların konusu olmuştur. Birçok probleme yol açan muhasebe hilelerinin niçin yapıldığg ile ilgili en önemli çalışma yukarıda da değinilen ve Cressey (1973)'in hile (ya da yolsuzluk) üçgeni (Fraud Triangle) olarak teorileştirdiği ve hile yapanların niçin hile yaptıklarını açıklayan teorik çalışmasıdır. Cressey, muhasebe hilesi yapanlar üzerinde yaptığı araştırmaların sonucunda, hile yapılmasını etkileyen başlıca üç faktöre (yukarıda bahsedilen baskı, firsat ve haklı gösterme) işaret etmektedir.

Hile için insanı hile yapmaya iten bir güdünün, bir saikin olması gerekir. Cressey, firmanın nakit durumunun zayıflığının, pazar kaybetmesinin, sektörde yoğun bir rekabetin varlığının firma açısından hileli davranışları motive eden unsurlar olduğunu vurgulamaktadır. Meslek mensupları açısından ise hileli davranışı motive eden unsurlar olarak, çalışanın faturalarını ödemekte güçlük çekmesi, kumar ve benzeri olumsuz alışkanlıklara sahip olması, lüks yaşama arzusu ve sektörde var olan yoğun rekabetin firmaların müşteri kaybetme (dolayısıyla gelir kaybetme) korkusuna sebep olduğu bilinmektedir. Mesleğe girişin zor olmaması, meslek mensupları arasında özellikle fiyat rekabetinin çok yoğun yaşanması (minimum ücret tarifelerinin altında fiyat verilmesi), tutulacak defter sayısı konusunda bir sınırlamanın olmaması (bir meslek mensubu yüzlerce defter tutarken, bir diğerinin yeterli sayıda deftere sahip olmaması gibi) Cressey'in baskı (motivasyon) olarak adlandırdığı bu unsurun meslek mensupları arasında var olan "rekabet" sebebiyle görülebileceği düşünülmektedir.

Koşullar veya içinde bulunulan ortam, insanların yolsuzluk yapmasına firsat oluşturmaktadır. Cressey'e göre, kontrol ve denetim mekanizmalarının hiç olmaması veya çok zayıf olması, hile yapılması için bir firsat penceresi açmaktadır. Muhasebe meslek mensuplarının mesleklerini icra ederken sık sık vergi aflarının çıkması, kanunlarda meslek mensuplarının kullanabileceği ve suç teşkil etmeyen çok sayıda yasal boşluğun bulunması, cezai yaptırımların yetersiz olması, denetimlerin yetersiz olması gibi nedenlerle meslek mensuplarının hileli davranışlara başvurabildiği görülmektedir. Cressey'in hile üçgenine uygun olarak, meslek mensupları açısından "mevzuat"1n bir firsat olarak görülebileceği düşünülmektedir.

Cressey, kişilerin dürüst olmayan, gayrimeşru iş, fiil ya da eylemlerini zihinlerinde bahaneler/gerekçeler oluşturarak meşrulaştırdığını (rasyonelleştirme) vurgular. Muhasebe meslek mensupları hile gibi etik dış1 davranışların asıl suçlusunun kendilerinin değil mükellefler olduğunu, kendilerinin sadece mükellefler tarafından tevdi edilen belgeleri defterlere işlediklerini, belgelerin doğruluğunun ya da yanlışlığının birinci derecede mükellefleri ilgilendirdiğini, sistemde denetimlerin ve cezaların caydırıcı boyutlarda olmadığını, mükellef lehine yasal boşluklardan faydalanmanın normal bir davranış olduğunu ve kendilerinin bu tür işlemleri yapmaması durumunda bir başkasının mükellefin isteğini yerine getirebileceğini bunun da kendileri için müşteri kaybı anlamına gelebileceğini düşünerek hileli eylemlere ortak olabilmekte ve bunu belirtilen sebeplerle rasyonelleştirebilmektedirler.

Literatürde Cressey'in hile üçgeni teorisinin dışında, muhasebe meslek mensuplarının niçin hileli davranışlarda bulundukları ile ilgili yapılan çalışmalarda üç farklı unsurun daha rol oynadığı görülmektedir. Bunlar; meslek mensuplarının meslek etiği değerlerine sahip olup olmamaları, meslek mensuplarının sahip oldukları muhasebe kültür değerleri ve meslek mensuplarının kişilikleridir. 


\subsection{Kültür}

Ülkelerin muhasebe sistemini etkileyen önemli faktörlerden biri olan kültür, toplum tarafından ortak olarak oluşturulan ve paylaşılan değerler ve davranışlar bütünüdür. Kültür kavramını uluslararası boyutta çalışan ilk kişi Hofstede (1984) olmuştur. Hofstede, insanların içinde yaşadıkları kültürün onların iş yapma biçimlerini etkilediğini vurgulamış ve kültürle ilgili pek çok çalışmaya da ilham kaynağı olmuştur. Hofstede'nin kültürel değerlerini muhasebe ile ilişkilendiren kişi Gray (1984)'dir. Gray, bir ülkenin muhasebe alt kültürünü tanımlamak için dört adet muhasebe değer boyutu belirlemiştir. Bunlar; profesyonelliğe karşı statükoculuk, tekdüzeciliğe karşı esneklik, tutuculuğa karşı iyimserlik ve gizliliğe karşı şeffaflıktır. Bu muhasebe değerleri de o ülkedeki muhasebe uygulamalarını etkilemektedir.

\subsection{Kișilik}

Hile olgusu muhasebecinin kişilik özellikleri ile de ilgilidir. Ramamoorti (2008), Cressey (1973) tarafından geliştirilen ve hilenin nedenlerini ortaya koyan hile üçgeninin, hile davranışını açıklamada çok yararlı olduğunu; ancak, hile üçgeninde yer alan faktörlerin yanında kişiliğin de özellikle kriminal olaylarda hileyi açıklamada önemli bir açıklayıcı faktör olduğunu ifade etmiştir. Yine Duffield ve Grabosky (2001) çalışmalarında, hile davranışına neden olan psikolojik faktörleri açıklarken kişiliğin de hile üzerindeki etkisine işaret etmişlerdir. Bununla birlikte kişilik üzerine yapılan çalışmalarda genellikle kişiliğin iş performansı üzerine etkisine odaklanılmıştır. İş performansı üzerine yapılan birçok çalışmada (Barrick ve Mount, 1993; Gellatly, 1996) kişiliğin iş performansını etkilediği ortaya konulmuştur. Serbest muhasebecilik mesleği açısından düşündüğümüzde, Ashton (1999), doğuştan gelen kişilik özelliklerinin muhasebede performansın belirleyicisi olarak kullanılabileceğini ifade etmiştir. Dolayısıyla hile davranışı, kötü bir performans ölçüsü olarak alındığında, kişilik özelliklerinin hile davranışını açıklamada belirgin bir faktör olacağını söylemek yanlış olmayacaktır.

\subsection{Etik Değerler}

Muhasebe meslek mensuplarının, muhasebe mesleğinin sahip olduğu itibar ve şahsiyete uygun biçimde davranmaları ve mesleki gereklilikleri yerine getirmeleri için öncelikle mesleğe karşı bir aidiyet ve sevgi duymaları gerekmektedir. İyi bir eğitim, yetenek ve deneyime sahip olunmalıdır. Tüm bunların yanında muhasebe meslek mensubu, meslek onuruna yakışır bir şekilde mesleki etik ilkeler ve kurallarını iş yaşamının içerisinde kendisine bir düstur edinmelidir (Uyar, 2005, s. 2; Kaya 2014, s. 77).

Muhasebe meslek mensuplarının sundukları bilgilerin doğru ve güvenilir olması, meslek mensuplarının tarafsızlık, gizlilik, dürüstlük, güvenilirlik ve sorumluluk gibi mesleki etik kurallarına uymalarına bağlıdır. Unutulmamalıdır ki, muhasebe meslek mensuplarının meslek etiğine uymaları veya uymamaları toplumun geniş kesimlerini etkilemektedir.

Etik dışı davranış, kişilerin, grupların ve toplumun veya mesleğin doğru, iyi olarak kabul ettiği etik ilkeler ve kuralların terk edilmesi, aykırı davranılması olarak tanımlanabilmektedir (Sökmen ve Tarakçığlu, 2013, s. 62). Kişisel çıkarlar doğrultusunda etik uygulamaların dışına çıkılarak meslek onuruyla bağdaşmayacak birtakım davranışlar gerçekleştirilebilmektedir (Bilen ve Y1lmaz, 2014: 69)

Etik dışında kalan davranışlar kişinin psikoloji kaynaklı olumsuz davranışlarından başlamak suretiyle toplumsal hastalıklara kadar uzanan bir oluşumun sonucunda ortaya çıkmaktadır (Steinberg ve Austern, 1996, s. 36; Gül, 2006, s. 71). Diğer bir deyişle, kişinin kendi içsel süreçlerinin yanında, dış çevresel etmenlerin de etkisi altında olduğunu söylemek mümkündür (Akdoğan, 2003, s. 12).

Yıldız'a (2001, s. 4-5) göre muhasebe meslek mensuplarını çıkar sağlamaya yardımcı olmak, daha az vergi ödemeyi sağlamak, kayıtlar üzerinde oynamalar yapmak gibi etik dışı davranışlara yönlendiren nedenler şöyle sıralanmaktadır (Zeytin, 2007, s. 109-110): 
- Mükellefle olan dostluk ilişkileri,

- Haksiz rekabet,

- Daha fazla kazanma hirsı,

- Mükellefi kaybetmemek istenmesi,

- Mevcut vergi ve ekonomik koşulların adil görülmemesi,

- Mükellefi koruma,

- Başarılı görünme arzusu.

Genel olarak etik dışı davranışların altında yatan nedenler iki sınıfta incelenebilmektedir. Bunlar kişisel nedenler ve kişisel olmayan nedenlerdir.

\subsubsection{Kişisel Sebepler}

Etik dışı davranışlarda kişisel sebepler; meslek mensubu kişilerin yetersizlikleri, zaafları, eksiklikleri ya da ikilemleri kaynaklıdır. Meslek mensubunun mesleki faaliyetler için uygun davranışları gösterebilmesi için gerekli olan anlama yeteneği, zihinsel yetenek ve olgunluk, karar verme, problem çözme, iletişim kurma gibi özelliklerinin yeterli ölçüde olmaması sebebiyle ortaya çıkabilen bazı davranışlar söz konusu olabilmektedir. Meslek mensubu kişiler bu eksiklikler sebebiyle etik ilkeleri farklı yorumlama, bencil davranma, mesleki bilgi yetersizliği gibi durumlar yaşamaktadır (Akdoğan, 2003, s. 12). Meslek mensubu kişilerin, kendilerinden kaynaklı bu eksiklikleri gidermedikleri sürece rasyonel davranmaları olanaksız olmakta ve hata yapma payları artmaktadır. Böyle bir durumda da aldığ 1 sorumluluklar, işini kaybetme gibi baskılar sebebiyle etik dışı bazı davranışlara yönlenebilmektedir (Karacan, 2014, s. 45).

\subsubsection{Dış Kaynaklı Sebepler}

Etik dışı davranışlarda dış kaynaklı sebepler; rekabet, meslek ücreti, mükelleften gelen baskılar ve zorlama kaynaklıdır. Rekabette haksız boyutlara ulaşılması, meslek onuruyla bağdaşmayan haksız kazançlara ve birtakım uygulamalara yol açabilmekte, etik dışı davranışlara sebep olabilmektedir. Muhasebe meslek mensupları arasında rekabete yönelik düzenlenmiş olan yasaklara rağmen gizli bir rekabet söz konusu olmaktadır. Bu rekabet durumu da bazı kişilerde etik dışı davranışları doğurabilmektedir (İşgüden, 2007, s. 66). Bir diğer dışsal sebep de meslek ücreti olarak gösterilebilir. Mesleki faaliyetler yerine getirilirken sağlanan kazancın maddi ve psikolojik anlamda doyum sağlamaması halinde etik dışı davranışlara yönlenme söz konusu olabilmektedir (Akdoğan, 2003, s. 15).

Muhasebe mesleği mensupları için bir diğer dışsal sebep ise mükelleften gelen baskılar ve zorlamalar olarak görülmektedir. İşletmelerin vergi matrahını azaltmak yoluyla vergi kaçırmak gibi çıkarlar doğrultusunda çeşitli gerçeği ifade etmeyen belgeler ve bilgiler temin etmesi ve sunmasıyla beraber meslek mensubu tarafindan bilinerek veya bilinmeyerek kayda geçmesi sahte ve yanıltıcı belgeler kapsamında etik dışı uygulamalara girmektedir. Mükellefler bu tür konularda meslek mensubuna baskı uygulayarak etik dişı davranışlarda bulunması konusunda zorlama yapabilmektedir (Özbirecikli ve Ural, 2006, s. 111). Dönem karının az gösterilmesinin yanında fazla gösterilmesi de karşılaşılan bir durumdur. Mali tabloların şişirilerek, gerçek olmayan rakamlar gösterilerek, borçların gizlenerek işletmelerin durumunu olduğundan daha iyi durumda gösterilmesi de söz konusu olabilmektedir. Bu fiktif karlarla, işletmenin finansal durumunun iyi, kazançların mevcuttan daha fazla ve sürekli büyüyormuş gibi gösterilmesiyle mali tablolar aracıllğıyla karar vericileri etkilemek yoluna başvurulabilmektedir. Bu türden durumlar genel kabul görmüş muhasebe ilkelerine ve etik ilke ve kurallara aykırı bir durum oluşturmaktadır (Bilen ve Y1lmaz, 2014, s. 69-70).

\section{Literatür Taraması}

Yapılan literatür taramasında meslek etiği ile ilgili çok sayıda çalışmaya ulaşılmıştır. $\mathrm{Bu}$ çalışmaların ortak özelliği belirli bir il veya bölgede faaliyet gösteren muhasebe meslek mensuplarının meslek etiğine yönelik bakış açılarının tespit edilmesi ve bunların yaş, mesleki 
tecrübe, cinsiyet, unvan, eğitim düzeyine göre farkl1lık gösterip göstermediğinin istatistiki olarak ortaya konulmasıdır. Türkiye'de bu konuda yapılan bazı çalışmalara aşağıda yer verilmiştir.

Aymankuy ve Sarığlan (2005), çalışmalarında Balıkesir ilinde faaliyet gösteren muhasebe meslek mensuplarının meslek etiğine yaklaşımlarını tespit etmek amacıyla 40 meslek mensubu üzerinde anket yöntemi ile bir araştırma yapmıştır. Çalışmanın sonucunda meslek mensuplarının eğitim seviyesinin yüksek olmasına rağmen etik kavramının mesleki olarak uygulanabilirliği konusunda düşüncelerinin farklı olduğu ve meslek mensuplarının yarıya yakın bir kısmının etik kuralları benimsemedikleri sonucuna ulaşılmıştır.

Selimoğlu (2006) çalışmasında, muhasebe olgusu ile etik ilişkisini incelemiş, ulusal ve uluslararası açıdan etik olgusuna bakışı değerlendirmiştir. Çalışmanın sonucunda mesleki etik olgusunun ancak toplumun tüm kesimlerinin etkin bir şekilde katılımı ile gerçekleşebileceği, bu sebeple meslek ahlak kurallarını tamamlayıcı nitelikte yasal düzenlemelerin yapılmasının zorunlu olduğu, yeterince caydırıcı olmayan yasaların haksız rekabeti önleyemeyeceği ve gizlilik ve güvenilirliği sağlayamayacağı çıkarımında bulunmuştur.

Bilen (2008), Doğu Anadolu Bölgesi’nde faaliyette bulunan meslek mensupları üzerinde yaptığı araştırma ile etik kuralların meslek mensupları tarafından önemsendiği ve kavrandığı sonucuna ulaşmıştır. Kutlu (2008) Erzurum ve Kars illerinde faaliyet gösteren meslek mensupları üzerinde yaptığı araştırmasında, muhasebe meslek mensuplarının etik ikilem yaşadığı ve yoğunluğunun kişilerin yaşına, gelirine ve müşteri sayısı gibi değişkenlere bağlı olarak farklılaştığı, müşteri kaybetme endişesinin bu ikilemde rol oynadığı, özellikle kültürel çevreye verilen önemin, yaşın ve eğitim seviyesinin etik ikileminden çıkışta farklılığa sebep olduğunu tespit etmiştir.

Yıldız (2010) araştırmasında, Kayseri'de faaliyet gösteren meslek mensuplarının etik konusunu önemsediği ve bu konuda eğitimin gerekli olduğuna inandığı; uygulama sırasında mükellef-kamu çıkar çatışması olduğunda kamu yararını önemsediği ve muhasebenin temel kavramlarından sosyal sorumluluk kavramına uygun davrandığı sonucuna ulaşmıştır. Ayrıca yetersiz mali denetim, kayıt dışı ekonomi, siyasi görüş farklılıkları gibi unsurların meslek mensuplarını etik dışı davranışlara yönelttiği sonucu çalışmanın diğer önemli bir bulgusudur. Sakarya ve Kara (2010), Balıkesir, Bursa, İstanbul ve İzmir'de faaliyet gösteren meslek mensupları üzerinde meslek etiğinin algılanma düzeyini tespit etmek amacıyla gerçekleştirdiği araştırma sonucunda; cinsiyet, unvan, tecrübe, mükellef sayısı açısından anlamlı farklılıklara rağmen eğitim düzeyine göre meslek etiğinin algılanmasında herhangi bir fark olmadığı sonucuna ulaşmıştır.

Kutluk ve Ersoy (2011) muhasebe meslek mensuplarının etik yargı düzeylerini ve bunun demografik değişkenler açısından farklılık taşıyıp taşımadığını tespit etmek amacıyla 150 meslek mensubu üzerinde yaptıkları araştırmalarında, meslek mensuplarının etik yargı düzeyinin "geleneksel" düzeyde olduğu, sadece cinsiyete göre sonuçlar arasında farklılık olup bunun da kadın meslek mensuplarının etik yargı düzeyi puanının erkeklere göre daha yüksek olduğu, unvan, öğrenim durumu, yaş ve tecrübe açısından anlamlı bir fark olmadığı sonucuna ulaşmıştır.

Güney ve Çınar (2012), çalışmalarında Serbest Muhasebeci Mali Müşavirlerin Etik Algılarını Erzurum ilinde faaliyet gösteren 102 meslek mensubu üzerinde araştırmıştır. Çalışmanın sonucunda, meslek mensuplarının etik ilkeleri önemsedikleri ve bu ilkelere aykırı uygulamaları tasvip etmedikleri, eğitim ve gelir düzeyi arttıkça etik ilkelere bağl1lı̆̆ı da arttığ sonuçlarına ulaşmıştır.

Dağdeviren (2014), Antalya, Burdur ve Isparta (Göller Bölgesi) illerinde faaliyet gösteren 311 bağımsız meslek mensubunun etik değerlere yönelik algısını ölçmek amacıyla yaptığı çalışmasında, meslek mensuplarının, mesleki etik konusunda yeterli yasal düzenleme bulunmaması ve sık mevzuat değişikliği yapılmasının etik dışı davranmaya sebep olduğu 
düşüncesine sahip oldukları ve erkek meslek mensuplarının bayanlara nispeten daha fazla etik dışı uygulamalara yöneldikleri sonuçlarına ulaşmıştır.

Yücel ve Kartal (2014) Serbest Muhasebeci Mali Müşavirlerin etik algılarını deontolojik olarak ortaya koymak ve mesleki faaliyetleri üzerindeki etkilerini incelemek amaciyla İstanbul ilinde faaliyet gösteren 500 meslek mensubu üzerinde yaptıkları araştırmanın sonucunda, meslek mensuplarının yarıya yakın kısmının etik ilkeleri uygulamaları bakımından zafiyet gösterdikleri, mükellef sayısı ve mesleki tecrübe ile etik ilkelere uyum arasında negatif bir ilişki olduğu sonuçlarına ulaşmıştır.

Anuk (2015), muhasebe meslek mensuplarının hata-hile ve etik konularındaki düşüncelerini ortaya koymak ve bu kavramlara yönelik düşüncelerinin katılımcıların demografik özelliklerine göre farklılaşıp farklılaşmadığını tespit etmek amacıyla 108 meslek mensubu üzerinde anket yöntemiyle bir araştırma yapmış, sonuçları; cinsiyet, yaş, eğitim düzeyi ve mesleki tecrübe ve unvan açılarından değerlendirmiştir. Çalışmanın sonucunda, cinsiyete ve unvana göre hile ve etik kavramlarına yönelik ifadelere katılımın farklılık göstermediği; yaşa, eğitim seviyesine ve mesleki tecrübeye gör farkl1lık gösterdiği tespit edilmiştir.

Okay (2016) çalışmasında; Diyarbakır ilinde faaliyet gösteren bağımsız muhasebe meslek mensuplarını etik dışı davranışa ve hata yapmaya yönlendiren faktörlerin neler olduğunu ve bazı değişkenler ile etik dışı davranışa yönlendiren temel faktörler arasındaki ilişkileri araştırmıştır. Çalışmanın sonucunda bağımsız muhasebe meslek mensuplarının etik dışı davranışa yönelmelerini önleyen etkenlerin başında, meslek mensuplarının devlete ve mesleki etiğe olan bağlılığı olarak görülmüş; etik dışı davranışa yönelten gerekçeler arasında "devletin adil bir vergi sisteminin olmaması" birinci sebep olarak gösterilmiştir.

Temiz vd. (2018) çalışmalarında hile senaryoları karşısında muhasebe meslek mensupları, muhasebe çalışanları ve işletme bölümü öğrencilerinin etik tutumları ve raporlama eğilimlerindeki farklılıkları incelemiştir. Anket sonucunda üç grup katılımcı arasında etik tutumları ve raporlama eğilimleri bakımından anlamlı farklılıklar olduğu tespit edilmiştir. Ayrıca raporlama eğiliminin en yüksek olduğu hile türünün yolsuzluk hile türü olduğu, en düşük raporlama eğiliminin ise mali tablo hileleri olduğu sonucuna varılmıştır.

Doğan vd. (2018) muhasebe meslek mensuplarının hileye eğilim düzeylerini tespit etmek amacıyla 53 meslek mensubu üzerinde anket yöntemi ile yaptıkları araştırmalarında, verilen cevaplar açısından cinsiyet, yaş, unvan ve çalışma sürelerine bağlı olarak katılımcılar arasında bir fark olmadığı, sadece eğitim durumlarına bağlı olarak lisans ve yüksek lisans mezunları arasında fark olduğu sonucuna ulaşılmıştır.

\section{Muhasebe Meslek Mensuplarının Etik Yaklaşımları ile Hileye Yönelme Eğilimleri Arasındaki İlişkiye Yönelik Ankara İlinde Bir Araştırma}

\subsection{Araștırmanın Amacı}

Araştırma, muhasebe meslek mensuplarının mesleki etik değerlere yaklaşımları ile hileye yönelme eğilimleri değişkenleri arasındaki bağlantıları ilişkisel olarak irdelemeyi amaçlamaktadır. Bu itibarla, muhasebe meslek mensuplarını hileye yönlendiren içsel ve dışsal unsurların belirlenmesi, bu kapsamda oluşturulan model doğrultusunda ele alınan değişkenler arasındaki ilişkilerin ve bu ilişkilerin yönünün ve demografik faktörlerin etkisinin ortaya konulması amaçlanmaktadır. Nihayetinde, araştırmanın sonuçları itibariyle muhasebe meslek mensuplarının hile karşısındaki mevcut durumuna ilişkin profilinin ortaya konulması ile literatüre bu yönden katkı sunulması araştırmanın temel amacını oluşturmaktadır. Muhasebe meslek mensuplarının etik değerlere olan yaklaşımları ile hileye yönelme eğilimleri arasında elde edilecek istatistiki sonuçlarla, Türkiye'de muhasebe mesleğinin ilke bazlı gelişimine önemli katkı sağlanması beklenmektedir. 


\subsection{Araștırmanın Önemi}

Muhasebe meslek mensuplarının sundukları verilerin doğru ve güvenilir olması, meslek mensuplarının tarafsızlık, gizlilik, dürüstlük, güvenilirlik ve sorumluluk gibi mesleki etik kurallarına uymalarına bağlıdır. Muhasebe meslek mensuplarının meslek etiğine uymaları veya uymamalarının toplumun geniş kesimlerini etkilediği bilinmektedir.

Muhasebe meslek mensuplarının hazırlayıp sunduğu mali bilgilerin güvenilir olması ve gerçeğe uygun sunum, meslek mensuplarının hileli davranışlardan uzak durmaları ile mümkündür. Meslek mensuplarının hazırlayıp sunduğu veriler hileli ise, bunun bir dizi olumsuz sonucu olacaktır.

Muhasebe meslek mensuplarının mesleklerini icra ederlerken hileli işlemler yapmaları önemli bir problem alanıdır. Bu problemin nedenlerinin tespiti ve bu nedenlerin ortadan kaldırılmasına dönük çözüm önerilerinin geliştirilmesi, genel olarak ekonomiye ve özelde de devlete, işletmelere, topluma ve bireylere fayda sağlayacaktır. Çünkü muhasebe hilesi yapılması durumunda bundan başta devlet olmak üzere, işletmeler, toplum, bireyler ve ekonomi bir bütün olarak zarar görmektedir.

Özetle, yaptıkları işlemler devleti, işletmeleri, bireyleri, ekonomiyi etkileyen muhasebe meslek mensuplarının, işlerini yasalara ve meslek etik kurallarına uygun olarak yapmamalarının, başka bir ifadeyle hileli işlemlere başvurmalarının nedenleri, araştırılmaya değer önemli bir problem kaynağıdır. Bu anlamda hileye yönelme noktasındaki olumsuz davranışların önüne geçilmesinde etik değerlerin büyük bir payı olduğu düşünülmektedir.

\subsection{Materyal ve Yöntem}

\subsubsection{Araştırmanın Yöntemi}

Araştırmada veri toplama aracı olarak anket tekniği kullanılmış ve birincil verilere dayandırılmıştır. Anket formu iki ana bölümden oluşmaktadır. İlk bölümde Ankara ilinde 2019 yılı içerisinde Serbest Muhasebeci Mali Müşavir (SMMM) ve Yeminli Mali Müşavir (YMM) olarak faaliyet gösteren muhasebe meslek mensuplarının demografik özelliklerini ölçmeye yönelik cinsiyet, yaş, mesleki tecrübe ve mesleki duruma ilişkin 4 soru yer almaktadır. İkinci bölümde ise muhasebe meslek mensuplarının 5'li Likert Ölçeği'ne göre muhasebe meslek etiğini benimseme durumlarını ölçümlemeye yönelik on altı ifade ve hile konusunda güdülenme eğilimlerini ölçümlemeye ilişkin sekiz ifade yer almaktadır. Anket formundan elde edilen veri seti SPSS 24 İstatistik Paket Programı ile analiz edilmiştir. Elde edilen veri setinin istatistiksel ölçümlemelere uygun olduğunun tespiti amacıyla güvenilirlik ve tutarlılık testleri yapılmıştır. Bu kapsamda Cronbach's Alpha ve KMO değerleri baz alınmıştır. Ayrıca faktör analizinden, fark testleri olan t-testi ve tek yönlü varyans analizi (One- way anova) ve post-hoc testlerinden istifade edilmiştir. Değişkenler arasındaki ilişkilerin ortaya konması amacıyla korelasyon ve regresyon analizlerine yer verilmiştir.

Araştırmanın ölçeği bu çalışmaya özgü olarak geliştirilmiş bir ölçektir. Araştırma temel varsayımlarına ilişkin olarak ifadeleri belirleyebilmek amacıyla literatür destekli olarak Ankara ve Trabzon illerinde yarı yapılandırılmış mülakat yöntemi ile toplanan veriler değerlendirilerek ölçek geliştirme yolu izlenmiştir. Burada amaç, araştırma anketini hazırlarken, meslek mensuplarını hileli işlem yapmaya sevk eden tüm unsurların araştırma anketine dahil edilmesini sağlamaktır.

\subsubsection{Araştırmanın Modeli ve Hipotezleri}

Araştırmanın varsayımları çerçevesinde değişkenlerin ve faktörlerin birbiri arasındaki ilişkileri, bu ilişkilerin yönlerini içeren ve oluşturulan hipotezlerin hangi ilişkileri araştırdığına ilişkin bir ön izleme ortaya koyan model aşağıda sunulmuştur. 


\section{Şekil 1. Araştırma modeli}

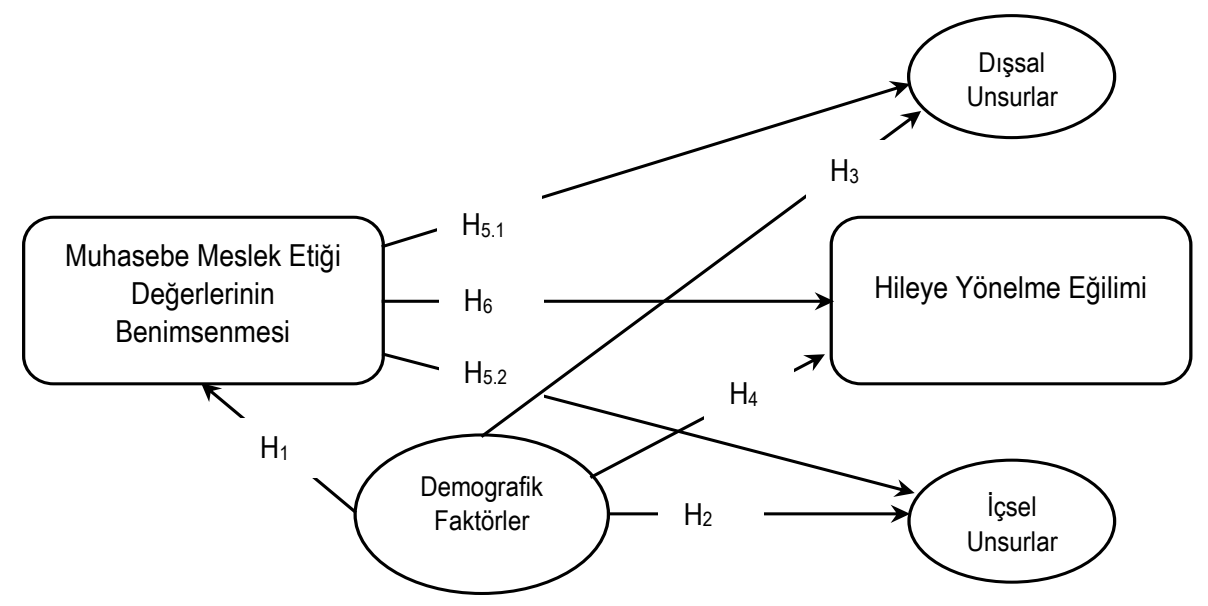

Araştırmanın amaçları doğrultusunda verilen bu model çerçevesinde oluşturulmuş olan hipotezler ve araştırma sonucunda desteklenme durumları aşağıda Tablo 1'de sunulmuştur:

Tablo 1. Oluşturulan hipotezler ve desteklenme durumları

\begin{tabular}{|c|c|c|c|}
\hline HİPOTEZLER & Desteklendi & Desteklenmedi & $\begin{array}{c}\text { Kismen } \\
\text { Desteklendi }\end{array}$ \\
\hline $\begin{array}{l}\mathrm{H}_{1} \text {. Demografik faktörlere göre muhasebe meslek etiği } \\
\text { değerlerinin benimsenmesi farkl1lık göstermektedir. }\end{array}$ & & & $\checkmark$ \\
\hline $\begin{array}{l}\mathrm{H}_{1.1 .} \text { Cinsiyete göre muhasebe meslek etiği } \\
\text { değerlerinin benimsenmesi farklılık göstermektedir. }\end{array}$ & & $\mathrm{X}$ & \\
\hline $\begin{array}{l}\mathrm{H}_{1.2 .} \text { Yaşa göre muhasebe meslek etiği değerlerinin } \\
\text { benimsenmesi farklılık göstermektedir. }\end{array}$ & $\checkmark$ & & \\
\hline $\begin{array}{l}\mathrm{H}_{1.3} \text {. Mesleki tecrübeye göre muhasebe meslek etiği } \\
\text { değerlerinin benimsenmesi farkl1lı göstermektedir. }\end{array}$ & & $\mathrm{X}$ & \\
\hline $\begin{array}{l}\mathrm{H}_{2 .} \text { Demografik faktörlere göre hileye yönelten içsel } \\
\text { unsurlar farkl1lık göstermektedir. }\end{array}$ & & $\mathrm{X}$ & \\
\hline $\begin{array}{l}\mathrm{H}_{2.1 .} \text { Cinsiyete göre hileye yönelten içsel unsurlar } \\
\text { farkl11ık göstermektedir. }\end{array}$ & & $\mathrm{X}$ & \\
\hline $\begin{array}{l}\mathrm{H}_{2.2 .} \text { Yaşa göre hileye yönelten içsel unsurlar } \\
\text { farklılık göstermektedir. }\end{array}$ & & $\mathrm{X}$ & \\
\hline $\begin{array}{l}\mathrm{H}_{2.3 .} \text { Mesleki tecrübeye göre hileye yönelten içsel } \\
\text { unsurlar farklılık göstermektedir. }\end{array}$ & & $\mathrm{X}$ & \\
\hline $\begin{array}{l}\mathrm{H}_{3 .} \text { Demografik faktörlere göre hileye yönelten dışsal } \\
\text { unsurlar farklılık göstermektedir. }\end{array}$ & & & $\checkmark$ \\
\hline $\begin{array}{l}\mathrm{H}_{3.1 .} \text { Cinsiyete göre hileye yönelten dişsal unsurlar } \\
\text { farklılık göstermektedir. }\end{array}$ & & $\mathrm{X}$ & \\
\hline $\begin{array}{l}\mathrm{H}_{3.2 .} \text { Yaşa göre hileye yönelten dişsal unsurlar } \\
\text { farklılık göstermektedir. }\end{array}$ & $\checkmark$ & & \\
\hline $\begin{array}{l}\mathrm{H}_{3.3 .} \text { Mesleki tecrübeye göre hileye yönelten dışsal } \\
\text { unsurlar farklılık göstermektedir. }\end{array}$ & $\checkmark$ & & \\
\hline $\begin{array}{l}\mathrm{H}_{4} \text {. Demografik faktörlere göre hileye yönelme eğilimi } \\
\text { farkl11lk göstermektedir. }\end{array}$ & & & $\checkmark$ \\
\hline $\begin{array}{l}\mathrm{H}_{4.1 .} \text { Cinsiyete göre hileye yönelme eğilimi farklılık } \\
\text { göstermektedir. }\end{array}$ & & $\mathrm{X}$ & \\
\hline $\begin{array}{l}\mathrm{H}_{4.2 .} \text { Yaşa göre hileye yönelme eğilimi farklılık } \\
\text { göstermektedir. }\end{array}$ & $\checkmark$ & & \\
\hline
\end{tabular}


$\mathrm{H}_{4.3 .}$ Mesleki tecrübeye göre hileye yönelme eğilimi $\mathrm{X}$

farklılık göstermektedir.

$\mathrm{H}_{5}$. Muhasebe meslek etik değerlerin benimsenmesi ile

hileye yönelten unsurlar arasında negatif ilișki

bulunmaktadir.

$\mathrm{H}_{5.1}$. Muhasebe meslek etik değerlerin

benimsenmesi ile hileye yönelten içsel unsurlar

arasında negatif ilişki bulunmaktadır.

$\mathrm{H}_{\text {5.2. }}$ Muhasebe meslek etik değerlerin

benimsenmesi ile hileye yönelten dişsal unsurlar

arasında negatif ilişki bulunmaktadır.

$\mathrm{H}_{6}$. Muhasebe meslek etik değerlerin benimsenmesi ile

hileye yönelme eğilimi arasında negatif ilişki

bulunmaktadır.

\subsection{Araştırmanın Bulguları}

Araştırmanın bu bölümünde, muhasebe meslek mensubu 360 katılımcıdan oluşan örneklemden toplanan verilerin istatistiksel analizlerinin sonuçlarına ilişkin açıklamalarda bulunulmuştur.

\subsubsection{Tanımlayıcı İstatistikler}

Araştırma kapsamında yanıtlarından istifade edilen muhasebe meslek mensuplarının cinsiyet, yaş, mesleki tecrübe ve mesleki durumdan (bağımlı/bağımsız) oluşan demografik özellikleri bakımından dağılımına ilişkin frekans analizi sonuçları aşağıdaki tabloda verilmiştir.

Tablo 2. Katılımcıların demografik özelliklerine ilişkin veriler

\begin{tabular}{|c|c|c|c|c|c|}
\hline Özellikler & Frekans & $\%$ & Özellikler & Frekans & $\%$ \\
\hline Cinsiyet & & & \multicolumn{3}{|l|}{ Mesleki Durum } \\
\hline Erkek & 299 & 83 & Bağımlı & 135 & 37,5 \\
\hline Kadın & 61 & 17 & Bağımsız & 225 & 62,5 \\
\hline Toplam & 360 & 100 & Toplam & 360 & 100 \\
\hline Yaș & & & \multicolumn{3}{|l|}{ Mesleki Tecrübe } \\
\hline 25 ve alt & 7 & 2 & 5 y1l ve alt1 & 23 & 6 \\
\hline $26-35$ & 126 & 35 & $6-10$ y1l & 61 & 17 \\
\hline $36-45$ & 192 & 53 & $11-15$ y1l & 111 & 31 \\
\hline 45 ve üzeri & 35 & 10 & $16-20 \mathrm{y} 1 \mathrm{l}$ & 112 & 31 \\
\hline Toplam & 360 & 100 & 21 y1l ve üzeri & 53 & 15 \\
\hline & & & Toplam & 360 & 100 \\
\hline
\end{tabular}

Araştırma sonucunda elde edilen demografik verilere ilişkin olarak verilen tablo incelendiğinde katılımcıların çoğunluğunu \%83 oran ile erkek meslek mensuplarının oluşturduğu görülmektedir. Yaş faktörüne bakıldığında 26-35 yaş aralığının \%35 oran ile ve 36-45 yaş aralığının \%53 oran ile dağılımın çoğunluğu oluşturduğunu söylemek mümkündür. Katılımcıların 135'i bağımlı, 225'i ise bağımsız meslek mensubudur. Demografik değişkenler içerisinde, bağımlı ve bağımsız meslek gruplarına yönelik farkın testi, normallik ve homojenlik şartını sağlamadığ1 için (Kolmogorio Smirnoc $p=0,00$; Shapiro-Wilk $p=0,00 \quad n=135 / 225$ ) analiz kapsamına dahil edilmemiştir. Katılımcıların mesleki tecrübeleri irdelendiğinde ise 11-15 yıl aralığı ile 16-20 yıl aralığının ağırlıklı olduğu gözlemlenmektedir.

Araştırmanın ölçek ifadelerine katılım bakımından frekans analizine tabi tutulduğunda ortaya çıkan sonuçlar itibariyle tablo aşağıdaki şekilde oluşmuştur. 
Tablo 3: Betimsel istatistikler tablosu

\begin{tabular}{|c|c|c|c|c|c|}
\hline İFADE & $\bar{x}$ & MED. & MOD & $\sigma$ & $\sigma^{2}$ \\
\hline Muhasebe Meslek Etiği Değerleri & & & & & \\
\hline $\begin{array}{l}\text { 1. Yasama organı, kanunların yapım sürecinde kasti } \\
\text { olarak boşluk bırakarak; meslek mensuplarına esneklik } \\
\text { sağlamakta bu da meslek mensuplarının haklı olarak } \\
\text { bu boşluklardan yararlanmalarına gerekçe olmaktadır. }\end{array}$ & 2,23 & 2,00 & 1 & 1,16 & 1,34 \\
\hline $\begin{array}{l}\text { 2. Devletin meslek mensubundan aşırı bilgi talebi, etik } \\
\text { gibi konulara öncelik verebilecek zamanı ortadan } \\
\text { kaldırmaktadır. }\end{array}$ & 2,86 & 3,00 & 3 & 1,40 & 1,97 \\
\hline $\begin{array}{l}\text { 3. Meslek ahlakına aykırı davranışların cezai } \\
\text { yaptırımlardaki yetersizlik muhasebe meslek } \\
\text { mensuplarını etik dış1 davranma konusunda } \\
\text { cesaretlendirmektedir. }\end{array}$ & 2,43 & 2,00 & 2 & 1,19 & 1,43 \\
\hline $\begin{array}{l}\text { 4. Muhasebe meslek mensuplarının etik dışı } \\
\text { davranışlarının nedeni sadece konu ile ilgili yasal } \\
\text { düzenlemeleri eksik bilmeleri ya da yanlış } \\
\text { yorumlamalarıdır. }\end{array}$ & 3,11 & 3,00 & 3 & 1,30 & 1,70 \\
\hline $\begin{array}{l}\text { 5. Yasal mevzuat hazırlanırken meslek mensuplarının } \\
\text { görüşleri yeterince alınmaması yasalara uymamanın } \\
\text { haklı bir sebebidir. }\end{array}$ & 1,90 & 1,00 & 1 & 1,131 & 1,28 \\
\hline $\begin{array}{l}\text { 6. Meslek mensupları mevzuatla ilgili her türlü soruya } \\
\text { cevap verebilecek kapasitededir. }\end{array}$ & 2,28 & 2,00 & 1 & 1,24 & 1,53 \\
\hline $\begin{array}{l}\text { 7. Meslek mensupları tüm mesleki ve iş ilişkilerinde } \\
\text { doğru sözlü ve dürüst davranmaktadır. }\end{array}$ & 2,53 & 3,00 & 3 & 1,20 & 1,45 \\
\hline $\begin{array}{l}\text { 8. Mükelleflerin haksız ve uygunsuz şekilde yaptıkları } \\
\text { baskılar, meslek mensuplarının mesleki kararlarını } \\
\text { etkilemez. }\end{array}$ & 3,04 & 3,00 & 2 & 1,35 & 1,83 \\
\hline $\begin{array}{l}\text { 9. Meslek mensupları mesleki faaliyetlerini yerine } \\
\text { getirirken teknik ve mesleki standartlara uygun olarak } \\
\text { özen ve gayret içinde davranmaktadır. }\end{array}$ & 2,36 & 2,00 & 2 & 1,01 & 1,02 \\
\hline $\begin{array}{l}\text { 10. Meslek mensupları mükellefleri ile ilgili bilgileri } \\
\text { ilgisiz kişi ve kurumlara hiçbir şekilde } \\
\text { açıklamamaktadır. }\end{array}$ & 2,48 & 2,00 & 1 & 1,23 & 1,52 \\
\hline $\begin{array}{l}\text { 11. Meslek mensupları mevcut yasa ve yönetmeliklere } \\
\text { her halükarda uymakta ve mesleğin itibarını } \\
\text { zedeleyecek her türlü davranıştan her daim } \\
\text { kaçınmaktadır. }\end{array}$ & 2,57 & 2,00 & 2 & 1,20 & 1,44 \\
\hline $\begin{array}{l}\text { 12. Daha çok kazanma isteği meslek mensubunun } \\
\text { zaman zaman etik dışı davranmasına neden olmaktadır. }\end{array}$ & 3,26 & 4,00 & 4 & 1,28 & 1,64 \\
\hline $\begin{array}{l}\text { 13. Daha fazla defter tutarak sektörde önemli bir yere } \\
\text { gelme düşüncesi, meslek mensubunun zaman zaman } \\
\text { etik dışı davranmasına neden olmaktadır. }\end{array}$ & 3,40 & 3,00 & 3 & 1,21 & 1,47 \\
\hline $\begin{array}{l}\text { 14. Meslek mensupları ile müşteri işletme arasında } \\
\text { oluşan duygusal ilişki (kendini mükellefle } \\
\text { özdeşleştirme) mükellef lehine uygulamaların } \\
\text { yapılmasına neden olmaktadır. }\end{array}$ & 3,53 & 4,00 & 4 & 1,14 & 1,30 \\
\hline $\begin{array}{l}\text { 15. Politik ve siyasi görüşlerdeki farklılıklar mesleki } \\
\text { etik kurallarına uyumu zorlaştırmaktadır. }\end{array}$ & 3,52 & 4,00 & 5 & 1,30 & 1,69 \\
\hline $\begin{array}{l}\text { 16. Meslek mensupları hukuki sorumluluklarını her } \\
\text { zaman ve her şartta yerine getirmektedirler. }\end{array}$ & 2,20 & 2,00 & 1 & 1,10 & 1,22 \\
\hline Hileye Yönelme Eğilimi & $\bar{x}$ & MED. & MOD & $\sigma$ & $\sigma^{2}$ \\
\hline
\end{tabular}




\begin{tabular}{|c|c|c|c|c|c|}
\hline İFADE & $\bar{x}$ & MED. & MOD & $\sigma$ & $\sigma^{2}$ \\
\hline $\begin{array}{l}\text { 17.Ülkenin içerisinde bulunduğu ekonomik durum } \\
\text { (ekonomik kriz, kayıt dış1 ekonominin büyüklügü, } \\
\text { vergi oranlarının yüksek ve çeşitlerinin fazla oluşu vb.) } \\
\text { mükelleflerin vergi ödememe eğiliminin haklı bir } \\
\text { sebebidir. }\end{array}$ & 3,01 & 3,00 & 5 & 1,53 & 2,35 \\
\hline $\begin{array}{l}\text { 18.Af uzlaşma vb. uygulamalar meslek mensubunu } \\
\text { mevzuata aykırı işlemler yapma konusunda } \\
\text { cesaretlendirmektedir. }\end{array}$ & 3,78 & 4,00 & 5 & 1,35 & 1,83 \\
\hline $\begin{array}{l}\text { 19.Meslek mensupları müşterilerin baskısı nedeniyle } \\
\text { yasal mevzuatın dıșına çımaktadır. }\end{array}$ & 3,72 & 4,00 & 5 & 1,39 & 1,95 \\
\hline $\begin{array}{l}\text { 20.Meslek mensupları arasındaki rekabet meslek } \\
\text { mensuplarını mesleğe uymayan davranışlara } \\
\text { yöneltmektedir }\end{array}$ & 4,23 & 5,00 & 5 & 1,18 & 1,41 \\
\hline $\begin{array}{l}\text { 21.Meslek mensuplarının etik dışı dahi olsa yaygın } \\
\text { olarak yaptıkları uygulamalar beni de aynı } \\
\text { uygulamaları yapmaya itmektedir. }\end{array}$ & 2,69 & 3,00 & 3 & 1,35 & 1,84 \\
\hline 22. Yasal olan her davranış aynı zamanda ahlakidir. & 2,11 & 2,00 & 2 & 0,98 & 0,96 \\
\hline $\begin{array}{l}\text { 23.Öncelikli olarak mükellef sorumlu olduğu için } \\
\text { mükellefin talebi doğrultusunda yapılan etik dışı } \\
\text { işlemlerden vicdani sorumluluk duyulmasına gerek } \\
\text { yoktur. }\end{array}$ & 2,82 & 3,00 & 2 & 1,27 & 1,62 \\
\hline $\begin{array}{l}\text { 24.Yapacağım yanlış bir muhasebe uygulamasııın } \\
\text { ortaya çıkarılma ve cezalandırılma olasılığı düşükse bu } \\
\text { uygulamayı yapmaya devam ederim. Ortaya çıkarılma } \\
\text { ve cezalandırma ihtimali yüksekse bu uygulamayı } \\
\text { yapmam. }\end{array}$ & 2,32 & 2,00 & 2 & 1,20 & 1,44 \\
\hline
\end{tabular}

$\overline{\mathrm{x}}=$ Ortalama, Med= medyan, $\sigma=$ standart sapma, $\sigma 2=$ varyans

Muhasebe meslek etiği değerleri ölçeğinin ifadeleri ortalama bazında incelendiğinde katılımcıların 1'e en yakın (Tamamen katılıyorum) verdikleri yanıt itibariyle 5. İfade öne çıkmıştır. İlgili ifadede yasal mevzuat hazırlanırken meslek mensuplarının görüşlerinin yeterince alınmadığına dair bir yargı söz konusudur. Bunun yanı sıra ortalaması 1'e yakın ifadeler itibariyle "meslek mensuplarının hukuki sorumluluklarını her zaman ve her şartta yerine getirdiğine, meslek mensuplarının mevzuata yönelik sorulara cevap verebilecek kapasitede olduğuna, mesleki faaliyetlerini yerine getirirken mesleki ve teknik standartlara uygun olarak gerekli gayret ve özen içerisinde davranmakta olduğuna dair" ifadeler yanıtlayıcılar tarafindan en fazla destek gören ifadeler olmuştur.

Hileye yönelme eğilimini ölçen ifadeler içerisinde ortalamalar, mod ve medyan bakımından incelendiğinde en düşük değeri gösteren, diğer bir deyişle 1'e doğru yaklaşmak suretiyle hile eğiliminin katılma düzeyi yükselen ifade, aynı zamanda hilenin diş unsurunu oluşturan ifadelerden biri olan af ve uzlaşma gibi uygulamaların meslek mensubunu mevzuata aykırı işlemler yapma konusunda cesaretlendirdiğine ilişkin ifadedir. Bunun aksine, yüksek skora sahip olan ifade ise yapılan yanlış bir muhasebe uygulamasının ortaya çıkarılma ve cezalandırılma olasılığı düşükse bu uygulamayı yapmaya devam etme, ortaya çıkarılma ve cezalandırma ihtimali yüksekse bu uygulamayı yapmamaya yönelik ifadedir.

\subsubsection{Araştırma Değişkenlerinin Test Edilmesi}

Elde edilen veri seti ışığında değişkenlerin homojenliğini, araştırma kapsamında ele alınan ölçeğin ve kurgulanmış olan araştırma modelinin güvenilirliğini ve tutarlılığını tespit etmek amaciyla Cronbach's Alpha ve Kaiser- Mayer- Olkin (KMO) ve Faktör Analizi değerleri incelenmiştir. 
Güvenilirlik katsayısı olan Cronbach's Alpha değeri 0'dan 1'e doğru yaklaştıcça iç tutarlılığın artmakta olduğu kabul edilmekte ve sosyal bilimlerde güvenilir olarak kabul edilen değer 0,6 olarak baz alınmaktadır (Kurtuluş, 2010: 246). Elde edilen veri setinin yeterliliğini ve faktör analizine uygunluğunu test eden KMO değeri de aynı şekilde 0'dan 1'e doğru yaklaştıkça istatistiksel ölçme gücü artmakta ve sosyal bilimlerde kabul edilen düzey olarak 0,5'ten büyük olmasi temel alınmaktadır (Kalayc1, 2010: 321).

$\mathrm{Bu}$ doğrultuda yapılan testler sonucunda 16 ifadeden oluşan muhasebe meslek etik değerleri değişkenine ilişkin Cronbach's Alpha katsayısı 0,826 ve KMO değeri 0,835 ( $p=0,000)$ bulunmuştur. Elde edilen bu sonuçlar araştırmanın bu değişkeninin ölçümlenebilme açısından oldukça güvenilir ve tutarlı olduğunu ortaya koymaktadır.

Yine aynı testler 1şığında toplamda 8 ifadeden oluşan hileye yönelme eğilimi değişkenine ilişkin elde edilen Cronbach's Alpha katsayıs1 0,746 ve KMO değeri 0,760 $(\mathrm{p}=0,000)$ olmuştur. Sonuçlar ise bu değişkenin de istatistiksel anlamda ölçümlenebilir olarak kabul edilen sınırların üzerinde olduğu ve bu değişkenin uygunluğunun tespit edildiğini söylemek mümkündür.

Ölçeklerdeki ifadeler 5'li Likert ölçeği kapsamında; 1. Tamamen katılıyorum ... 5. Hiç katılmıyorum şeklinde ele alınmış olup, muhasebe meslek etik değerleri açısından ortalamalar 1'e doğru yaklaştıkça meslek mensubunun etik değerleri skorunun yüksek olduğu çıarımını yapmak mümkündür. Bu noktada verilen ifadeler içerisinde yer alan ters ifadelerin ters kodlama yoluyla uygun hale getirildiği ve böylece tamamının l'e yaklaştıkça olumlu bir yanıt olarak ele alınması gerektiğini belirtmek gerekmektedir. Hileye yönelme eğilimi değişkeninde ise verilen ifadeler hileli davranışlara yönelmek anlamında ortalamalar 1'e yaklaştıkça hileye yönelme eğiliminin arttığı, 5'e yaklaştıkça ise azaldığını söylemek mümkün olacaktır. Bu noktada bir varsayım olarak etik değerleri yüksek olan mensubun hileye yönelme eğiliminin düşük olması, diğer bir deyişle etik değerlerin ortalamasının 1'e yakın olduğu takdirde hileye yönelme eğiliminin 5'e yakın değerler göstermesi beklenmektedir. Buradan çıkarılacak olan anlam etik değer skoru yüksek olan mensubun hile eğilimi skorunun düşük olması, tam tersi halinde ise etik değer skoru düşük olan mensubun hile eğilimi skorunun yüksek olması beklenmektedir. Genel sonuç itibariyle etik değerler ile hile arasında bir ilişkinin var olduğu ve bu ilişkinin negatif yönlü olarak ortaya çıkması beklenmektedir.

Faktör analizinde Büyüköztürk'e (2002: 474), Yaşlığlu'na (2017: 75) ve Kline’a (1996: 133) göre faktör yükünün 0,3 'ten yüksek olması analizde değerlendirilmesi yönünden yeterlidir. $\mathrm{Bu}$ bilgiler ışığında katılımcılara yönlendirilmiş olan ifadelerin faktör yüklerine göre dağılımı aşağıda verilmiştir.

\begin{tabular}{|c|c|c|c|}
\hline & İfadeler & 1 & 2 \\
\hline 1 & $\begin{array}{l}\text { Yasama organı, kanunların yapım sürecinde kasti olarak boşluk bırakarak; } \\
\text { meslek mensuplarına esneklik sağlamakta bu da meslek mensuplarının } \\
\text { haklı olarak bu boşluklardan yararlanmalarına gerekçe olmaktadır. }\end{array}$ & & 615, \\
\hline 2 & $\begin{array}{l}\text { Devletin meslek mensubundan aşırı bilgi talebi, etik gibi konulara öncelik } \\
\text { verebilecek zamanı ortadan kaldırmaktadır. }\end{array}$ & ,449 & \\
\hline 3 & $\begin{array}{l}\text { Meslek ahlakına aykırı davranışların cezai yaptırımlardaki yetersizlik } \\
\text { muhasebe meslek mensuplarını etik dışı davranma konusunda } \\
\text { cesaretlendirmektedir. }\end{array}$ & 633 & \\
\hline 4 & $\begin{array}{l}\text { Muhasebe meslek mensuplarının etik dışı davranışlarının nedeni sadece } \\
\text { konu ile ilgili yasal düzenlemeleri eksik bilmeleri ya da yanlış } \\
\text { yorumlamalarıdır. }\end{array}$ & ,497 & \\
\hline 5 & $\begin{array}{l}\text { Yasal mevzuat hazırlanırken meslek mensuplarının görüşleri yeterince } \\
\text { alınmaması yasalara uymamanın haklı bir sebebidir. }\end{array}$ & & ,464 \\
\hline 6 & $\begin{array}{l}\text { Meslek mensupları mevzuatla ilgili her türlü soruya cevap verebilecek } \\
\text { kapasitededir. }\end{array}$ & ,516 & \\
\hline
\end{tabular}




\begin{tabular}{|c|c|c|c|}
\hline & İfadeler & 1 & 2 \\
\hline 7 & $\begin{array}{l}\text { Meslek mensupları tüm mesleki ve iş ilişkilerinde doğru sözlü ve dürüst } \\
\text { davranmaktadır }\end{array}$ & ,749 & \\
\hline 8 & $\begin{array}{l}\text { Mükelleflerin haksız ve uygunsuz şekilde yaptıkları baskılar, meslek } \\
\text { mensuplarının mesleki kararlarını etkilemez }\end{array}$ & 629, & \\
\hline 9 & $\begin{array}{l}\text { Meslek mensupları mesleki faaliyetlerini yerine getirirken teknik ve } \\
\text { mesleki standartlara uygun olarak özen ve gayret içinde davranmaktadır }\end{array}$ & ,712 & \\
\hline 10 & $\begin{array}{l}\text { Meslek mensupları mükellefleri ile ilgili bilgileri ilgisiz kişi ve kurumlara } \\
\text { hiçbir şekilde açıklamamaktadır }\end{array}$ & ,480 & \\
\hline 11 & $\begin{array}{l}\text { Meslek mensupları mevcut yasa ve yönetmeliklere her halükarda uymakta } \\
\text { ve mesleğin itibarını zedeleyecek her türlü davranıştan her daim } \\
\text { kaçınmaktadır }\end{array}$ & 659 & \\
\hline 12 & $\begin{array}{l}\text { Daha çok kazanma isteği meslek mensubunun zaman zaman etik dışı } \\
\text { davranmasına neden olmaktadır }\end{array}$ & ,823 & \\
\hline 13 & $\begin{array}{l}\text { Daha fazla defter tutarak sektörde önemli bir yere gelme düşüncesi, } \\
\text { meslek mensubunun zaman zaman etik dış1 davranmasına neden } \\
\text { olmaktadır }\end{array}$ & ,781 & \\
\hline 14 & $\begin{array}{l}\text { Meslek mensupları ile müşteri işletme arasında oluşan duygusal iliş̧ki } \\
\text { (kendini mükellefle özdeşleştirme) mükellef lehine uygulamaların } \\
\text { yapılmasına neden olmaktadır }\end{array}$ & ,595 & \\
\hline 15 & $\begin{array}{l}\text { Politik ve siyasi görüşlerdeki farklılıklar mesleki etik kurallarına uyumu } \\
\text { zorlaştırmaktadır }\end{array}$ & & ,573 \\
\hline 16 & $\begin{array}{l}\text { Meslek mensupları hukuki sorumluluklarını her zaman ve her şartta } \\
\text { yerine getirmektedirler }\end{array}$ & ,570 & \\
\hline
\end{tabular}

Araştırmada alt boyut gözetilmeksizin etik değerler bir bütün olarak ele alınmıştır. Ancak faktör analizinden elde edilen sonuçlar ışığında yanıtlayıcıların 1, 5 ve 15. ifadeleri bir boyutta kalan tüm ifadeleri ise diğer bir boyut altında algıladıklarını göstermektedir. Ayrışan bu üç ifadeye bakıldığında politik ve yasal içerikli ifadeler oldukları görülmekte, bu yönüyle ayrıştığı düşünülmektedir.

Araştırmanın diğer bir değişkenini oluşturan hileye yönelme eğilimine ilişkin faktör analizi sonuçları ise aşağıdaki tabloda verilmiştir.

Tablo 5: Hileye yönelme eğilimi değişkeninin faktör yükleri

\begin{tabular}{llcc}
\hline & İfadeler & 1 & 2 \\
\hline 1 & $\begin{array}{l}\text { Meslek mensuplarının etik dışı dahi olsa yaygın olarak yaptıkları } \\
\text { uygulamalar beni de aynı uygulamaları yapmaya itmektedir. }\end{array}$ &, 401 & \\
\hline 2 & Yasal olan her davranış aynı zamanda ahlakidir. &, 824 & \\
\hline 3 & $\begin{array}{l}\text { Öncelikli olarak mükellef sorumlu olduğu için mükellefin talebi } \\
\text { doğrultusunda yapılan etik dışı işlemlerden vicdani sorumluluk duyulmasına } \\
\text { gerek yoktur. }\end{array}$ &, 888 \\
\hline 4 & $\begin{array}{l}\text { Yapacağım yanlış bir muhasebe uygulamasının ortaya çıkarılma ve } \\
\text { cezalandırılma olasılığı düşükse bu uygulamayı yapmaya devam ederim. }\end{array}$ &, 795 \\
& $\begin{array}{l}\text { Ortaya çıkarılma ve cezalandırma ihtimali yüksekse bu uygulamayı } \\
\text { yapmam. }\end{array}$ &, 800 \\
\hline 5 & $\begin{array}{l}\text { Ülkenin içerisinde bulunduğu ekonomik durum (ekonomik kriz, kayıt dışı } \\
\text { ekonominin büyüklüğü, vergi oranlarının yüksek ve çeşitlerinin fazla oluşu } \\
\text { vb.) mükelleflerin vergi ödememe eğiliminin haklı bir sebebidir. }\end{array}$ &, 687 \\
\hline 6 & $\begin{array}{l}\text { Af, uzlaşma vb. uygulamalar meslek mensubunu mevzuata aykııı işlemler } \\
\text { yapma konusunda cesaretlendirmektedir }\end{array}$ &, 756 \\
\hline 7 & $\begin{array}{l}\text { Meslek mensupları müşterilerin baskısı nedeniyle yasal mevzuatın dışına } \\
\text { çımaktadır. }\end{array}$ & \\
\hline
\end{tabular}


8 Meslek mensupları arasındaki rekabet meslek mensuplarını mesleğe uymayan davranışlara yöneltmektedir.

Faktör analizi sonuçlarına göre hileye yönelme eğilimi değişkeninin iki alt boyutta toplandığ 1 görülmektedir. Tabloda görüleceği üzere ilk dört ifade bir boyutta, izleyen dört ifade ikinci bir boyutta yüklenmiş olarak ortaya çıkmıştır. Bu itibarla, tabloda verilen ilk dört ifadenin meslek mensubunun hileye yönelme açısından içsel güdülerini temsil etmektedir. Burada meslek mensubunun içsel durumuyla ilgili bir boyut söz konusudur. Hileye yönelme eğilimine içsel motivasyon kaynaklı dayanaklar bulmaya yönelik olduğu görülmektedir. Diğer dört ifadenin ise dış unsurlardan kaynaklanan birtakım nedenlere sığınarak ortaya çıkan bir eğilim gözlemlenmektedir. Ekonomik koşullar karşısında mükelleflerin durumu, mevzuat, müşteri ve rekabetin oluşturduğu baskılar gibi hileye yönelme eğiliminde dışsal kaynaklı dayanaklar söz konusudur. Ele alınan bu iki unsurun temeli hilenin altında yatan güdülerin içsel ve dışsal olarak ikiye ayrılabileceği varsayımına dayanmaktadır. Çalışmanın ölçeğinde varsayılan bu iç ve dış unsurların etkisi faktör analiziyle doğrulanmış bulunmaktadır.

$\mathrm{Bu}$ bilgiler doğrultusunda fark testleri ile gruplar arasında farklılık ortaya çıkıp çıkmadığının tespitini ortaya koyabilmek amacıyla iki seçime sahip olan cinsiyet faktörü için ttesti, yaş ve mesleki tecrübe faktörleri için tek yönlü varyans analizi (One-way anova) tekniği kullanılmıştır. Gruplar arasındaki farklılıkların kaynağını tespit etmek amacıyla Post-hoc testlerinden varyansların eşit dağılımı durumda LSD ve Tukey, eşit olmadığında kullanılan Games Howell ve Tamhane's T2 testleri kullanılmıştır. Anlamlılık düzeyi sosyal bilimlerde kabul gören değer olan $p \leq 0,05$ olarak diğer bir deyişle $\% 95$ güven düzeyi baz alınmıştır. Verilerin normallik testi sonucunda normal dağ 1 ım gösterdiği anlaşılmış ve parametrik testlere uygunluğu saptanmıştır.

Cinsiyet faktörü ele alınarak araştırma kapsamındaki değişkenler dahilinde farklılaşmayı irdeleyen t-testlerine ilişkin sonuçlar aşağıdaki tabloda verilmiştir.

Tablo 6. Cinsiyet faktörü T-testi

\begin{tabular}{lcrrrrr}
\hline Değișken & Ort. & S.S & t & df & p & Sig.(2-tailed) \\
\hline Mesleki Etik & & & & & & \\
\hline Kadın & 2,72 & 0,52 &,- 17 & 358 &, 198 &, 860 \\
\hline Erkek & 2,74 & 0,48 &,- 18 & 91,62 & & \\
\hline Hileye Yönelme & & & & & & \\
\hline Kadın & 3,05 & 0,77 & $-1,47$ & 358 & &, 142 \\
\hline Erkek & 3,21 & 0,76 & $-1,48$ & 86,93 &, 989 & \\
\hline Hileye Yönelme İç Unsur & & & & & & \\
\hline Kadın & 3,57 & 1,00 & $-1,37$ & 358 & & \\
\hline Erkek & 3,76 & 0,78 & $-1,61$ & 104,37 &, 019 & \\
\hline $\begin{array}{l}\text { Hileye Yönelme Dış } \\
\text { Unsur }\end{array}$ & & & & & &, 267 \\
\hline Kadın & 2,54 & 0,84 & $-1,11$ & 358 &, 309 & \\
\hline Erkek & 2,67 & 0,95 & $-1,02$ & 80,28 & & \\
\hline
\end{tabular}

Tablodaki veriler cinsiyet faktörü açısından ortaya çıkan sonuçların istatistiksel olarak anlamlı değerlerin üzerinde olduğunu göstermektedir. Diğer bir deyişle cinsiyet faktörü, ele alınan değişkenlerin tümü açısından herhangi anlamlı bir farklılık göstermemektedir. Elde edilen bu sonuçla beraber cinsiyet faktörünü ele alan H1.1, H2.1, H3.1 ve H4.1 hipotezinin desteklenmediği görülmektedir.

Cinsiyet dışında kalan yaş ve mesleki tecrübe faktörleri ise ikiden fazla grup içerdiğinden Anova Analizi ile analiz edilmiştir. Bu analizlere ilişkin istatistiksel sonuçlar aşağıdaki tabloda verilmiştir. Tabloda $\mathrm{N}$ sütunu katılımcıların her grup başına sayısını, $\overline{\mathrm{x}}$ sütunu yanıtların 1'den 
5'e kadar olan ortalamasını, S.S. sütunu standart sapmayı, P sütunu sigma anlamlılık düzeyini ifade etmektedir.

Tablo 7. Yaş faktörü tek yönlü varyans analizi

\begin{tabular}{|c|c|c|c|c|c|}
\hline Değişken & Yaş Grubu & $\mathrm{N}$ & $\bar{x}$ & S.S & $\mathrm{p}$ \\
\hline \multirow{4}{*}{$\begin{array}{l}\text { Muhasebe Meslek Etik } \\
\text { Değerleri }\end{array}$} & 25 ve alt 1 & 7 & 2,03 & 0,35 & \\
\hline & $26-35$ & 126 & 2,67 & 0,47 & ,001* \\
\hline & $36-45$ & 192 & 2,77 & 0,53 & \\
\hline & 46 ve üzeri & 35 & 2,80 & 0,52 & \\
\hline \multirow[t]{4}{*}{ Hileye Yönelme } & 25 ve alt 1 & 7 & 3,91 & 0,74 & \\
\hline & 26-35 & 126 & 3,19 & 0,75 & ,004* \\
\hline & $36-45$ & 192 & 3,01 & 0,75 & \\
\hline & 46 ve üzeri & 35 & 2,95 & 0,88 & \\
\hline \multirow[t]{4}{*}{ Hileye Yönelme İç Unsur } & 25 ve alt1 & 7 & 4,14 & 1,20 & \\
\hline & $26-35$ & 126 & 3,71 & 0,89 & ,164 \\
\hline & $36-45$ & 192 & 3,52 & 0,98 & \\
\hline & 46 ve üzeri & 35 & 3,55 & 1,03 & \\
\hline \multirow[t]{4}{*}{ Hileye Yönelme Dış Unsur } & 25 ve alt1 & 7 & 3,67 & 0,42 & \\
\hline & $26-35$ & 126 & 2,66 & 0,84 &, $001 *$ \\
\hline & $36-45$ & 192 & 2,49 & 0,82 & \\
\hline & 46 ve üzeri & 35 & 2,35 & 0,97 & \\
\hline
\end{tabular}

Tabloda görüldüğü üzere ele alınan değişkenler olan muhasebe meslek etik değerleri $(\mathrm{p}=0,001)$ ve hileye yönelme eğilimi $(\mathrm{p}=0,004)$ için yaş farklılaştırıcı bir faktör olarak ortaya çıkmıştır. Hileye yönelme eğiliminin iç ve dış unsurları açısından irdelendiğinde ise dış unsur anlamlı $(\mathrm{p}=0,001)$ bir fark yaratmış; ancak iç unsur açısından anlamlılık düzeyinin üzerinde kaldığından bir fark ortaya çıkmamıştır $(\mathrm{p}=0,164)$.

Ortaya çıkan anlamlı farklılaşmaların analizi için Post-hoc testlerine bakıldığında tüm değişkenler için 25 ve altı yaş gurubu ile diğer yaş gruplarının arasında en büyük farklılaşmanın oluştuğu görülmektedir. Bu durum tabloda verilen ortalamalar sütununda da gözlemlenmektedir. Buradan görüleceği üzere yaş düzeyi düştükçe muhasebe meslek etik değerleri ortalaması 1'e yaklaşmakta, diğer bir deyişle Tamamen katılıyorum seçeneğine yakın bir seyir göstermektedir. Hileye yönelme eğilimi açısından ise 5'e doğru yaklaşmakta, Hiç katılmıyorum seçeneğine yaklaşmaktadır. Buradan yapılabilecek olan çıkarımı yaşın farklılaştırıcı bir faktör olarak düzeyi yükseldikçe meslek etiğine verilen önemin azaldığı ve hileye olan eğilimin arttığı şeklinde belirtmek mümkün gözükmektedir. Bu itibarla yaş faktörüyle ilgili olan H1.2, H3.2 ve H4.2 hipotezinin desteklendiği, H2.2 hipotezinin desteklenmediği sonucuna ulaşılmıştır.

İdelenen diğer bir faktör olan mesleki tecrübe faktörünün araştırma değişkenleri açısından farklılaşma durumunu analiz eden tek yönlü varyans analizine ilişkin sonuçlar aşağıdaki tabloda verilmiştir.

Tablo 8. Mesleki tecrübe faktörü tek yönlü varyans analizi

\begin{tabular}{lrrrrr}
\hline Değişken & $\begin{array}{c}\text { Mesleki } \\
\text { Tecrübe }\end{array}$ & N & $\bar{x}$ & S.S & P \\
\hline Muhasebe Meslek Etik & 5 y1l ve alt1 & 23 & 2,69 & 0,47 & \\
\cline { 2 - 6 } Değerleri & $6-10$ yıl & 61 & 2,58 & 0,51 &, 122 \\
\cline { 2 - 7 } & $11-15$ y1l & 111 & 2,79 & 0,48 & \\
\cline { 2 - 7 } & $16-20$ yıl & 112 & 2,72 & 0,58 & \\
\hline Hileye Yönelme & 21 y1l ve üzeri & 53 & 2,73 & 0,46 & \\
& 5 y1l ve alt1 & 23 & 3,23 & 0,64 & \\
\cline { 2 - 7 } & $6-10$ yıl & 61 & 3,25 & 0,85 &, 188 \\
\hline
\end{tabular}




\begin{tabular}{|c|c|c|c|c|c|}
\hline & $11-15$ y1l & 111 & 3,04 & 0,66 & \\
\hline & $16-20 \mathrm{y} 1 \mathrm{l}$ & 112 & 3,07 & 0,83 & \\
\hline & 21 yıl ve üzeri & 53 & 2,93 & 0,79 & \\
\hline \multirow[t]{5}{*}{ Hileye Yönelme İç Unsur } & 5 y1l ve alt1 & 23 & 3,60 & 0,91 & \\
\hline & 6-10 y11 & 61 & 3,68 & 0,96 & ,943 \\
\hline & $11-15$ y1l & 111 & 3,61 & 0,92 & \\
\hline & $16-20 \mathrm{y} 11$ & 112 & 3,58 & 1,05 & \\
\hline & 21 y1l ve üzeri & 53 & 3,54 & 0,92 & \\
\hline \multirow[t]{5}{*}{ Hileye Yönelme Dış Unsur } & 5 y1l ve alt1 & 23 & 2,85 & 0,69 & \\
\hline & 6-10 y1l & 61 & 2,82 & 0,96 & $008 *$ \\
\hline & $11-15$ y1l & 111 & 2,47 & 0,74 & \\
\hline & $16-20 \mathrm{y} 11$ & 112 & 2,56 & 0,87 & \\
\hline & 21 y1l ve üzeri & 53 & 2,32 & 0,91 & \\
\hline
\end{tabular}

$* \mathrm{p}<0,05$ ile anlaml 1

Mesleki tecrübe faktörü mesleki etik ve hileye yönelme eğilimi değişkenleri açısından anlamlı düzeyin üzerinde kalarak istatistiksel anlamlı bir farklılık ortaya koymamıştır. Yalnızca hileye yönelme eğiliminin dış unsuru bakımından anlamlı farklılık söz konusudur $(\mathrm{p}=0,008)$. Burada post-hoc testleri sonucuna göre farkı oluşturan grupların 5 yıl ve altı ile 21 yıl ve üzeri olduğu görülmüştür. Ortalamalar itibariyle bakıldığında da mesleki tecrübenin artmasına paralel olarak hileye olan eğilimde dış unsurun etkisi artmaktadır. Diğer bir ifadeyle tecrübe arttıkça dış unsurlara dayanarak hileye yönelme eğiliminin artış göstermekte olduğu söylenebilir. Ancak bu durum iç unsur açısından böyle bir etki yaratmamıştır. Anlamlılık düzeyinin çok üzerinde $(\mathrm{p}=0,943)$ yer almış ve hileye yönelme eğilimi değişkenine de bu durum yansıyarak genel itibariyle anlamlı fark durumunu ortadan kaldırmıştır. Mesleki tecrübenin mesleki etik ile olan ilişkisi ortalamalar açısından incelendiğinde tecrübe arttıkça ortalamaların yükseldiği, diğer bir deyişle etik değerlerden uzaklaşmakta olduğu gözlemlenebilmekte, ancak bu etki, istatistiksel olarak anlamlı bir düzeyde olmamaktadır. Mesleki tecrübe faktörünün değişkenler için farklılaştırıcı bir faktör olarak ortaya çıkmadığı söylenebilir. Bu sonuçlarla beraber mesleki tecrübe faktörüne ilişkin olarak verilen H1.3, H2.3, H4.3 hipotezlerinin desteklenmediği ve yalnızca hileye yönelmede diş unsur faktörüne ilişkin olan $\mathrm{H} 3.3$ hipotezinin desteklendiği görülmektedir.

Demografik faktörlerin farkını ele alan temel hipotezlerden H1, H3 ve H4'ün kısmen desteklendiği ve H2'nin desteklenmediği görülmektedir.

Mesleki etik değerler, hileye yönelme eğilimi ve hileye yönelmede iç ve diş unsurlar arasındaki ilişkileri saptamak amacıyla tüm değişkenlerin ele alındığı ve birbirleri arasındaki ilişkileri, bu ilişkilerin yönünü ve gücünü ortaya koyan bir korelasyon analizi yapılmıştır. Veriler normal dağılım gösterdiğinden korelâsyon analizinde Pearson katsayı modeli çift kuyruk anlamlılık çerçevesinde kullanılmıştır.

Korelasyon analizi, değişkenler arasındaki karşılıklı ilişkiyi ve bu ilişkinin yönünü saptamak için başvurulan bir istatistiksel yöntemdir. Korelasyon neden- sonuç ilişkisine dair bilgi vermediği için değişkenlerin bağımlı veya bağımsız olması şartı aranmamaktadır (Nakip, 2013: 348). Korelasyon katsayısı -1 ile +1 arasında değerler almakta, değer +1 'e yaklaştıkça ilişkinin kuvveti artmakta, 0'a yaklaştıkça azalmaktadır. Kesin sınırlamalar olmamakla beraber 0,50 altındaki korelasyon zayıf, 0,50 ile 0,70 arasındaki değer orta ve 0,70 üzerindeki değer ise güçlü bir ilişkiyi göstermektedir (Durmuş vd., 2013:143-144). Negatif değerler ise değişkenler arasında ters yönlü ilişkinin olduğuna işaret etmektedir. konulmuştur.

Bu bilgiler kapsamında yapılan korelasyon analizinin sonuçları aşağıdaki tabloda ortaya 
Tablo 9. Araştırmanın değişkenleri arasındaki korelasyonlar

\begin{tabular}{llcccc}
\hline & & 1 & 2 & 3 & 4 \\
\hline 1 & Meslek Etiği Değerleri & 1 & & & \\
\hline 2 & Hileye Yönelme Eğilimi &,$- 520^{* *}$ & 1 & & \\
\hline 3 & Hileye Yönelme Eğilimi İç Unsur &,$- 407^{* *}$ &, $868^{* *}$ & 1 & \\
\hline 4 & Hile Yönelme Eğilimi Diş Unsur &,$- 482^{* *}$ &, $829^{* *}$ &, $442^{* *}$ & 1 \\
\hline
\end{tabular}

** Korelâsyon $\mathrm{p}<0,01$ anlamlılık düzeyinde, $\mathrm{p}=0,000$

Tablo incelendiğinde meslek etiği değerleri ile hile eğilimi arasında \%99 güven aralığında -,520 düzeyinde negatif ilişki olduğu görülmektedir. Buna paralel biçimde hile eğiliminin iç unsuru -,407 ve dış unsur -,482 düzeyinde negatif ilişki içerisindedir. Burada ortaya çıkan sonuç meslek etiği değerleri ile hileye eğilim arasında ters yönlü orta-güçlü düzeyde bir ilişki olduğudur. İç ve dış unsurlar hileye eğilim temel değişkeni ile güçlü bir ilişkiyi yansıtmaktadır. Bu durum regresyon analizinin ön koşulunu sağlamaktadır. Buradan hareketle, enter metoduyla gerçekleştirilen regresyon analizi sonuçları aşağıdaki tabloda verilmiştir.

Tablo 10. Araştırmanın değişkenlerine ilişkin regresyon analizi

\begin{tabular}{|c|c|c|c|c|c|c|c|c|}
\hline $\begin{array}{l}\text { Bağımsız } \\
\text { Değişken }\end{array}$ & Bağımlı Değişken & S.S & $\mathrm{F}$ & $\mathrm{p}$ & $\beta$ & $\mathrm{t}$ & $\mathrm{R}$ & $\mathrm{R}^{2}$ \\
\hline Meslek & Hileye Yönelme & $0,52 / 0,77$ & 133,025 & 0,000 & - & - & ,520 & 271 \\
\hline Etiği & Eğilimi & & & & ,777 & 16,057 & & \\
\hline \multirow[t]{2}{*}{ Değerleri } & $\begin{array}{l}\text { Hileye Yönelme İç } \\
\text { Unsur }\end{array}$ & $0,52 / 0,96$ & 70,894 & 0,000 & 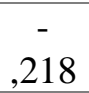 & $-8,420$ & 407 & , 165 \\
\hline & $\begin{array}{l}\text { Hileye Yönelme Diş } \\
\text { Unsur }\end{array}$ & $0,52 / 0,86$ & 108,562 & 0,000 & 292 & $\begin{array}{c}- \\
10,419\end{array}$ & , 482 & ,233 \\
\hline
\end{tabular}

Meslek etiği değerleri, hileye yönelme eğilimi ve hileye yönelme eğiliminin iç ve dış unsurları olarak ortaya konulan ilişki modeli, $\mathrm{F}=133,025, \mathrm{~F}=70,894, \mathrm{~F}=108,562$ ve tümü içim $\mathrm{p}=0,000$ ile istatistiksel olarak anlamlı bulunmuştur.

Meslek etiği değerleri ile hileye yönelme eğilimi arasında negatif yönlü -,777 değerinde bir ilişki söz konusudur. Buradan ele alınan bu ilişkinin negatif bağlamda güçlü olduğunu söylemek mümkündür. Meslek etiği değerlerinin hileye yönelme eğilimi üzerindeki değişimi açıklama gücü \%27,1'dir. Diğer bir ifade ile hileye yönelme eğilimindeki değişimin \%27,1'ini açıklamaktadır.

Meslek etiği değerleri ile hileye yönelmede iç unsurların ilişkisinde beta katsayısı -,218 ile negatif bağlamda etkilidir. Meslek etiği değerlerinin hileye yönelme eğilimindeki iç unsurların üzerindeki değişimi açıklama gücü \%16,5'tir. Meslek etiği değerleri ile hilenin dış unsurları ilişkisinde ise beta katsayısı -,292 ile etkili olarak ortaya çıkmıştır. Meslek etiği değerleri, hileye yönelme eğilimindeki iç unsurlardaki değişimin \%23,3'ünü açıklamaktadır.

$\mathrm{Bu}$ analizler sonucunda ortaya konulan ilişkiyi sınamak üzere verilen hipotezlerden $\mathrm{H} 5$, H5.1, H5.2 ve H6 desteklenmiştir.

\section{Sonuç ve Öneriler}

Muhasebenin temel ilkeleri meslek mensubunun tarafsızlığının, güvenilirliğinin, özenliliğinin ve şeffaflığının önemine vurgu yapmaktadır. Muhasebe meslek mensupları bu anlamda kamuoyuna, mükellefe ve devlete, kısaca karar alıcı tüm kesimlere karşı sorumlu bulunmakta ve mesleğini icra ederken dürüst ve ahlaki bir biçimde, muhasebe etiği ve kuralları çerçevesinde uygulamalar yapmak durumundadır. Toplumun tüm kesimlerini etkileyen böylesi önemli bir meslek hakkında sıkça etik tartışmalar gündeme gelmektedir.

Araştırma, muhasebe meslek mensuplarının mesleki etik değerlere olan yaklaşımlarını tespit etmek ve buradan yola çıkarak mesleki etik değerler ile hileye yönelme eğilimi arasında ilişkiyi ortaya koymayı amaçlamıştır. Bunun yanında meslek mensuplarının cinsiyet, yaş ve 
mesleki tecrübeden oluşan demografik faktörlerinin değişkenler bazında farklılaşma durumu irdelenmiştir.

Demografik faktörler açısından elde edilen sonuçlara göre cinsiyet hiçbir değiş̧ken için farklılaştırıcı bir faktör olarak bulunmamıştır. Fakat yaş faktörü mesleki etik değerleri ve hileye yönelme eğilimi değişkenleri için farklılık göstermiştir. Meslek mensuplarının yaş düzeyleri azaldıkça mesleki etik değerlere katılım puanları yükselmiştir. Hileye yönelme eğilimi açısından ise tam tersi durum söz konusudur. Bireyin yaşı yükseldikçe meslek etiğine verilen önemin azaldığı ve hileye olan eğilimin arttığı şeklinde bir çıkarım yapmak mümkündür. Mesleki tecrübe faktörü açısından ise ele alınan değişkenlerden yalnızca hileye yönelme eğiliminin dış unsurları bakımından farklılaşma gözlemlenmiştir.

Literatürdeki benzer çalışmalarda cinsiyete göre etik değerlerin (Okay, 2011; 2016) ve hilenin (Dağdeviren, 2014; Keskin, 2014; Özçelik vd., 2017; Öztoprak, 2017, Doğan vd., 2018) farklılaşmadığı, yaş açısından ise farklılaştığı (Anuk, 2015; Öztoprak, 2017) ve yaş düzeyinin yükselmesiyle beraber hileye olan eğilimin de yükseldiği bu çalışmaya paralel şekilde bulgulanmıştır. Ayrıca Sertifikalı Hile Denetçileri Derneği ACFE'nin 2016 yılında yayınladığ araştırma raporunda verilen hile yapan bireylerin profiline yönelik bulgulara göre yaş faktörünün düzeyinin yükselmesiyle hile yapma olasılığ 1 doğru orantılı bir şekilde artış göstermekte ve en çok hile yapanların ileri yaşa sahip bireyler oldukları ortaya konulmaktadır (ACFE, 2016). Bu çalışmada demografik faktörlerin fark testleri sonucunda ortaya çıkan bulgulardan bazıları ise adı geçen çalışmalardan farklı şekilde bulgulanmıştır. Bunlardan mesleki tecrübe etik değer açısından (Okay, 2011; 2016) ve hile açısından (Keskin, 2014, Özçelik vd., 2017) farklılaşmadığı, cinsiyetin etik değerler açısından farklılaştığının (Sakarya ve Kara, 2010; Kutluk ve Ersoy, 2011; Ağyar vd., 2012) bulgulandığı gözlemlenmiştir.

Sonuçlar irdelendiğinde verilen ifadeler içerisinde meslek mensuplarının katılımları bakımından öne çıkan bazı ifadeleri belirtmekte fayda olabileceği düşünülmektedir. Bu anlamda bakıldığında cevaplayıcılar mevzuat hazırlanırken meslek mensuplarının görüşlerinin yeterince alınmadığını düşünmektedir. Ülkenin içerisinde bulunduğu ekonomik durum (ekonomik kriz, kayıt dışı ekonominin büyüklüğü, vergi oranlarının yüksek ve çeşitlerinin fazla oluşu vb.) mükelleflerin vergi ödememe eğiliminin sebebi olabileceği düşünülmektedir. Af, uzlaşma gibi uygulamaların meslek mensubunu mevzuata aykırı işlemler yapma konusunda cesaretlendirdiğine, müşterilerin baskısı nedeniyle mevzuatın dışına çıkıldığına, meslek mensupları arasındaki rekabetin meslek mensuplarını mesleğe uymayan davranışlara yönelttiğine dair görüş öne çıkmıştır.

Yapılan bu çalışmada elde edilen bulgular itibariyle yapılabilecek en önemli çıkarım muhasebe meslek etiği ile hileye olan eğilim arasında negatif yönlü bir ilişkinin bulunduğudur. $\mathrm{Bu}$ anlamda meslek mensupları etik değerlere ne denli sahipse, o kadar hileye yönelme eğilimi azalmaktadır. Aksi halde ise etik değerler anlamında puanı düşük olan mensupların daha fazla eğilimi olduğunu düşünmek mümkündür. Buradan çıkarılabilecek sonuç meslek etiğinin önemini vurgulamaktadır. Hilenin önlenmesinde meslek etiğinin benimsenmesi büyük önem arz eden bir husus olarak ortaya çıkmaktadır. Çalışmanın genel yapısı itibariyle muhasebe meslek mensubunun hileye yönelme anlamında iç ve dış motivasyon bulması, onun etik değerlere sahip çıkmasıyla ilgili bir durum ortaya koymaktadır. Bu itibarla, etik değerlerin benimsenmesi yolunda büyük çaba sarf edilmesi gerektiği anlaşılmaktadır. Etik bilincinin aşılanması yönünde çalışmaların bu konuda fayda göstereceği düşünülmektedir.

Çalışmada kullanılan örneklem Ankara ili içerisindeki meslek mensuplarını kapsadığından elde edilen bulguların genelleştirilmesi doğru olmayacaktır. Örneklemin ülke genelinin yaklaşımını yansıtabilecek ölçüde farklı illerde yapılması daha kapsamlı bir sonuç elde etmek noktasında ve sonuçları genelleyebilmek için faydalı olacaktır. Ayrıca, bu çalışmada meslek etiği ile hile arasındaki etkiler araştırılmış, hileye yönelmede iç ve dış unsurlar şeklinde bir ayrımla meslek mensubunun hileli işlemlere başvurmasında kendine gerekçe olarak gördüğü 
alanların tespit edilmesine ilişkin bir model geliştirilmeye çalışmış ve literatüre bu yönde katkı sağlanması amaçlanmıştır. Gelecekte yapılacak olan çalışmalarda hile konusunun farklı boyutlarıyla analiz edilmesi ve sonuçlarının bu çalışmayla birlikte değerlendirilmesiyle, hilenin anlaşılması ve belki de önlenmesi konusunda çalışmamızın katkı sağlaması beklenmektedir.

\section{Kaynakça}

ACFE (2016), Report to the Nation on Occupational Fraud and Abuse. [Çevrim-içi: http://www.acfe.com/rttn-archive.aspx], Erişim Tarihi: 11.06.2017.

Ağyar, E., Kutluk, F. A. \& Cengiz, E. (2012). Meslek yüksekokulları muhasebe bölümü öğrencilerinin sosyo-ekonomik değişkenler ışığında mesleki etiğe bakış açılarının incelenmesi (Akdeniz üniversitesi örneği), Journal of Yasar University, 25 (7), 4203-4228.

Akdoğan, H. (2003). Muhasebe meslek etiğinin kamunun aydınlatılmasındaki önemine meslek mensuplarının yaklaşımları. (Yayımlanmamış doktora tezi), Anadolu Üniversitesi, Eskişehir.

Anuk, S. A. (2015). Muhasebe hata ve hileleri ile muhasebe mesleğinde etik. (Yayımlanmamış yüksek lisans tezi), Bahçeşehir Üniversitesi, İstanbul.

Ashton, R. H. (1999). Enriching the expertise paradigm of accounting research: conscientiousness, general cognitive ability and goal orientation. Unpublished doctoral dissertation, Texas A\&M University, Texas, USA.

Aymankuy, Y. ve Sarığlan, M. 2005. Muhasebe meslek mensuplarının meslek etiğine yaklaşımları ve Balıkesir il merkezinde bir uygulama. Balıkesir Üniversitesi Sosyal Bilimler Enstitüsü Sosyal Bilimler Dergisi, 8 (14), 23-45.

Barrick, R. M. \& Mount, K. M. (1993). Autonomy as a moderator of the relationships between the big five personality dimensions and job performance. Journal of Applied Psychology, 78 (1), 111-118.

Bilen, A. (2008). Doğu Anadolu Bölgesindeki muhasebe meslek mensuplarının profilleri, etik kurallarına bakışları ve meslek sorunları üzerine bir araştırma. Mali Çözüm, 85, 27-42.

Bilen, A. ve Yılmaz, Y. (2014). Muhasebe mesleğinde etik ve etikle ilgili çalışmalar. Dicle Üniversitesi İktisadi ve İdari Bilimler Fakültesi Dergisi, 2 (6), 57-72.

Büyüköztürk, Ş. (2002). Faktör analizi: temel kavramlar ve ölçek geliştirmede kullanımı. Kuram ve Uygulamada Eğitim Yönetimi, 32, 470-478.

Cressey, D. R. (1973). Other people's money; a study in the social psychology of embezzlement. Montclair, N.J.: Patterson Smith.

Dağdeviren, İ. E. (2014). Muhasebe Meslek mensuplarının etik algılamaları ve etik dışı davranışlara yönlendiren faktörler: Göller Bölgesinde bir araştırma. (Yayımlanmamış yüksek lisans tezi), Mehmet Akif Ersoy Üniversitesi, Burdur.

Doğan, Z., Gülçin, K. ve Nazlı, E. (2018). Muhasebe meslek mensuplarının hile yapmaya eğilim düzeylerinin tespitine ilişkin bir araştırma. Ömer Halisdemir Üniversitesi İktisadi ve İdari Bilimler Fakültesi Dergisi, 11 (4), 64-83.

Duffield, G. \& Grabosky, P. (2001). The psychology of fraud. Canberra: Australian Institute of Criminology.

Durmuş, B, Yurtkoru, E. S. ve Çinko, M. (2013). Sosyal bilimlerde SPSS'le veri analizi. İstanbul: Beta Basım Yayın.

Gellatly, R.I. (1996). Conscientiousness and task performance: test of cognitive process model. Journal of Applied Psychology, 81 (5), 474-482. 
Gray, S. J. (1988). Towards a theory of cultural influence on the development of accounting systems internationally. Abacus, 24, 1-15.

Gül, H. (2006). Etik dışı davranışlar ve ussallaştırılması: devlet hastanelerinde bir uygulama. Selçuk Üniversitesi Karaman İ̈BF Dergisi, 10 (9), 65-79.

Güney, S. ve Çınar, O. (2012). Serbest muhasebeci mali müşavirlerin (SMMM) etik algıları: Erzurum örneği. Atatürk Üniversitesi İIBF Dergisi, 26 (2), 91-106.

Hofstede, G. (1984). Cultural dimensions in management and planning. Asia Pacific Journal of Management, January, 81-99.

İşüden, B. (2007). Sosyal ve kültürel değerlerin muhasebe meslek etiği üzerine etkileri. (Yayımlanmamış yüksek lisans tezi), Balıkesir Üniversitesi, Balıkesir.

Kalaycı, Ş. (2010). SPSS uygulamalı çok değiş̧kenli istatistik teknikleri. Ankara: Asil Yayın Dağıtım.

Karacan, S. (2014). Etik kavramı ve muhasebe meslek etiği. Kocaeli: Umuttepe Yayınları.

Kaya, M. (2014). Kurumsal yönetim ilkelerinin muhasebe mesleki etik kuralları açısından değerlendirilmesi. (Yayımlanmamış yüksek lisans tezi), Sakarya Üniversitesi, Sakarya.

Keskin, S. (2014). Muhasebe hata ve hileleri karşısında etik tutumlar: meslek mensupları üzerine bir araştırma. (Yayımlanmamış yüksek lisans tezi), Süleyman Demirel Üniversitesi, Isparta.

Kline, P. (1996). An easy guide to factor analysis. London: Routledge.

Kurtuluş, K. (2010). Araştırma yöntemleri. İstanbul: Türkmen Kitabevi.

Kutlu, H. A. (2008). Muhasebe meslek mensupları ve çalışanlarının etik ikilemleri: Kars ve Erzurum illerinde bir araştırma. Ankara Üniversitesi SBF Dergisi, 63 (2), 143-170.

Kutluk, F. A. ve Ersoy, A. (2011). Muhasebe meslek üyelerinin etik yargı düzeyleri üzerine bir araştırma. Ege Akademik Bakış Dergisi, 11 (3), 425-438.

Nakip, M. (2013). SPSS destekli pazarlama araştırmalarına giriş. Ankara: Seçkin Yayıncılık.

Okay, S. (2011). Muhasebe hata ve hilelerinin meslek etiği açısından irdelenmesi. (Yayımlanmamış yüksek lisans tezi), Karamanoğlu Mehmetbey Üniversitesi, Karaman.

Okay, S. (2016). Muhasebe hata ve hilelerinin meslek etiği açısından incelenmesi: Diyarbakır örneği. Uluslararası Sosyal Araştırmalar Dergisi, 9 (44), 1151-1165.

Özbirecikli, M. ve Ural, T. (2006). muhasebe mesleğinde yaşanan etik dışı davranışların tespiti ve etiksel değerlendirmesi: Türkiye örneği. İktisat/ İsletme ve Finans Dergisi, 21 (248), 102119.

Özçelik, H., Karataş, A., Özlem N., Keskin, S. (2017). Muhasebe hata ve hileleri: meslek mensupları üzerine bir araştırma. Süleyman Demirel Üniversitesi Sosyal Bilimler Enstitüsü Dergisi, 29 (4), 197-214.

Öztoprak, Y. (2017). Denetimde hata ve hile, önleme ve tespit yöntemleri ile serbest muhasebeci mali müşavirlerin hata ve hileler ile ilgili bilinç ve tutumları. (Yayımlanmamış yüksek lisans tezi), İstanbul Gelişim Üniversitesi, İstanbul.

Ramamoorti, S. (2008). The psychology and sociology of fraud: integrating the behavioral sciences component into fraud and forensic accounting curricula. Issues in Accounting Education, 23 (4), 521-533.

Sakarya, Şakir ve Kara, Suat (2010). türkiye'de muhasebe meslek etiğine yönelik düzenlemeler ve meslek mensupları tarafindan algılanması üzerine bir alan araştırması, KMÜ Sosyal ve Ekonomik Araştırmalar Dergisi, 12 (18), 57-72. 
Selimoğlu, S. K. (2006). Türk muhasebe uygulamalarında etik. Mali Çözüm Özel Sayı, 437-456.

Sökmen, A. ve Tarakçığlu S. (2013). Mesleki etik, Ankara: Detay Yayıncılık.

Steinberg, S. S. \& Austern, D. T. (1996), Hükümet ahlak ve yöneticiler, (T. Ergün Çev.). Ankara: Türkiye ve Ortadoğu Amme İdaresi Yayını.

Temiz, H., Hacıhasanoğlu, T. \& Özdemir, N. (2018), Muhasebe meslek mensupları, muhasebe çalışanları ve meslek mensubu adaylarının hile tutumları ve raporlama eğilimlerinin incelenmesi: Yozgat örneği. Erciyes Üniversitesi İktisadi ve İdari Bilimler Fakültesi Dergisi, 52, 213-240.

Uyar, S. (2005). Muhasebe mesleğinde etikle ilgili düzenlemeler. [Çevrim-içi: http://www.muhasebetr.com/yazarlarimiz/suleyman/001], Erişim Tarihi: 11.03.2019.

Yaşlığlu, M. (2017). Sosyal bilimlerde faktör analizi ve geçerlilik: keşfedici ve doğrulayıcı faktör analizlerinin kullanılması. İstanbul Üniversitesi İsletme Fakültesi Dergisi, 46, 74-85.

Yıldız, F. (2001). Muhasebe mesleğinde meslek ahlakının önemi ve mesleğin saygınlığını azaltan etmenler. Trakya Üniversitesi Bilimsel Araştırma Dergisi Sosyal Bilimler C Serisi, 2, 40-41.

Yıldız, G. (2010). Muhasebe mesleğinde meslek etiği ve Kayseri il merkezinde bir uygulama. Erciyes Üniversitesi İktisadi ve İdari Bilimler Fakültesi Dergisi, 36, 155-178.

Yücel, R. ve Kartal, C. (2014). Muhasebecilerin mesleki uygulamalarındaki etik algılarına ilişkin bir araştırma. Klrkkkale Üniversitesi Sosyal Bilimler Dergisi, 4 (2), 123-148.

Zeytin, M. (2007). Bağımsız muhasebe meslek mensuplarını hata ve etik dışı davranışlara yönlendiren faktörler. (Yayımlanmamış yüksek lisans tezi), Dumlupınar Üniversitesi, Kütahya.

\section{ETIK ve BİLIMSEL İLKELER SORUMLULUK BEYANI}

$\mathrm{Bu}$ çalışmanın tüm hazırlanma süreçlerinde etik kurallara ve bilimsel atıf gösterme ilkelerine riayet edildiğini yazarlar beyan eder. Aksi bir durumun tespiti halinde Afyon Kocatepe Üniversitesi Sosyal Bilimler Dergisi'nin hiçbir sorumluluğu olmayıp, tüm sorumluluk makale yazarlarına aittir. 